\title{
DIET AND PLASMA CHOLESTEROL IN DAIRY COWS
}

\author{
Pellervo SaArinen \\ Department of Animal Husbandry, University of Helsinki
}

Received September 6, 1955

\section{Introduction}

Blood plasma is a very sensitive vehicle. Hence its value as an indicator of the effects of the dietary factors is often suspected. In constant controlled conditions the colesterol content of cow's blood plasma is, however, very stable. Changes in the ration of the cow, on the other hand, may result in great variations in the level of plasma cholesterol.

It was noticed in a previous study (23) that the plasma cholesterol content of apparently healthy cows on different rations and in different stages of lactation varies from about 50 to $300 \mathrm{mg} / 100 \mathrm{ml}$. Ten to twenty percent of the total amount of cholesterol was observed to be in the form of free cholesterol and $80-90$ percent esterified with fatty acids. It was also noticed that with dry solvents only a very small but variable part of the plasma lipids could be extracted from blood plasma as such or when buffered to $\mathrm{pH}$ 7.4. If, however, the plasma was either slightly acidified or alkalified and allowed to stand for some time, under certain conditions the lipids could be extracted quantitatively. Later it has been established that the main part of plasma cholesterol like other lipids is carried in the form of lipoprotein molecules. The proportions of proteins and lipids in these complexes are capable of change in different nutritional and disease states $(14,28)$. Additionally some absorbable surface active substances may alter the structure of these aggregates and affect the plasma lipid content ( 7 ). So there are several factors worthy of consideration when the problem presented in the title is analyzed. Very little, however, is known as yet about the details of these mechanisms.

When commencing this study, attempts were made to use the "free» and/or "bound" lipids as the indicator of the dietary effects. These investigations, however, did not produce satisfactory results. Of different plasma lipid fractions the cholesterol ester fatty acid fraction is best correlated with the milk and milk fat yield (23). On a constant feeding the amount of this fatty acid fraction, however, appears to be 
less constant than the total cholesterol content, which seems to be superior in indicating the effects of diet. The total cholesterol fraction is also better correlated with other plasma lipid fractions and hence reflects, to some extent, the level of other plasma lipids too. For the present the total cholesterol determination appears to be as good an indicator of dietary effects as any other lipid fraction, the lipo-protein complexes included. Similar conclusions about the significance of total cholesterol measurement in evaluation or prediction of atherosclerotic disease have been drawn by Keys (15). So the present discussion is concerned only with the total cholesterol in the blood plasma.

The cholesterol content of blood plasma is, obviously, the resultant of four processes regulating the ingo and outgo of cholesterol, i.e. 1) absorption and 2) synthesis on the one hand and 3) excretion and 4) destruction and/or conversion of the cholesterol on the other.

1. The cholesterol in diet can be absorbed, especially, when fed together with fat. The absorption, however, is limited. $(1,8,9$, ) In most cases the regulation mechanism appears to be adequate to prevent any large elevation of blood cholesterol, particularly if the ingestion of excess cholesterol is acute (7). In some animals, notably the rabbit and chicken a long continued addition of large amounts of cholesterol to the diet will induce chronic hypercholesteremia $(1,6,13)$ possibly due to the fact that some organ (e.g. liver) is damaged and fails to function efficiently (7). In preliminary tests conducted by the author, up to $50 \mathrm{~g}$ of pure cholesterol was fed daily to the cows for several days and only a slight rise in the plasma cholesterol was observed both when the cholesterol was fed as such or in emulsified oil solution. Because cholesterol is not contained in plant products the effect of cholesterol in the diet of ruminants generally appears to be negligible.

2. Cholesterol appears to be easily synthesized in the animal body particularly by the conversion of short-chain fatty acids. $(4,17,19,28)$ In ruminants volatile fatty acids are abundantly evolved in the reticulo-rumen. For other animals these are readily available from the metabolism of several nutrients, especially from fats.

Almost all organs are capable of synthesizing cholesterol. Recent experiments with laboratory animals appear to show, however, that the liver is the only organ supplying significant amounts of cholesterol to the blood plasma and is therefore the actual source of plasma cholesterol $(6,10,12)$.

3. Cholesterol is secreted in the bile and is also eliminated by intestinal excretion. In to the opinion of Byers and co-workers (7) the intestinal excretion of cholesterol is influenced, in part at least, by extremely high plasma levels of cholesterol but high plasma levels of cholesterol, rarely, if at all, result from decreased cholesterol excretion.

4. The liver apparently is also the organ principally concerned in the destruction or conversion of cholesterol. The major part of the cholesterol eliminated by the liver from blood plasma appears to be converted into cholic acid. 
The complete destruction as well as the conversion into fats, glycogen, steroid hormones etc. apparently plays only a minor role.

The changes in the rate of intrinsic destruction and/or conversion of plasma cholesterol on the one hand and the processes concerned with the synthesis of the cholesterol on the other seem to be the two factors chiefly regulating the plasma cholesterol content of healthy animals (7).

The vast majority of the literature concerned with the causes of the variations observed in the level of plasma cholesterol deals with pathological conditions. Hypercholesteremia and atherosclerotic disease, particularly, have been the objects of these studies. These problems have recently been thoroughly discussed, among others by Byers and co-workers $(7)$, Keys $(15,16)$ etc. Some of these results may also be cited here.

Hyperthyroidism has been shown to result in a low plasma cholesterol. In addition to the a marked increase in the rate of cholesterol synthesis, a moderate increase in intestinal excretion of cholesterol and coprosterol, a marked decrease in the half-life of plasma cholesterol and an increased rate of disappearance of injected cholesterol from the plasma of the hyperthyroid rat has been observed. The converse findings have been observed in the hyperthyroid rat (7). Low plasma cholesterol has also been observed in cows fed with iodinated casein.

Hepatocellular diseases are usually accompanied by hypocholesteremia, possibly due to the decrease in the rate of cholesterol synthesis. If, however, liver damage is associated with biliary obstruction (intrahepatic or extrahepatic) a retention of cholate occurs in plasma and the disease may result in increased plasma cholesterol. The same has been observed in biliary cirrhosis and other liver diseases associated with plasma cholate accumulation. Similar changes have been observed in renal disorders too (7).

In adrenal disorders rather wide variation in the blood cholesterol have been observed. It is, however, possible that these changes too are associated with the functional state of the liver (7).

Injections of estrogen have been reported to produce different results in different animals. In preliminary tests conducted by the author prior to the present study (unpublished), variable amounts of estrogen injected into lactating cows failed to show any distinct effects. Similar results were obtained when proportionally small amounts of cortisone and of ACTH were used for a shorter period of time. The variable results obtained elswhere with cortisone have been explained by the fact, that a prolonged administration of cortisone may lead to hypothyroidism which in turn might elevate plasma cholesterol $(7,26)$. In some experiments conducted by the author, however, a short time administration of proportionally large amounts of cortisone and ACTH too has increased the plasma cholesterol content.

Pregnancy is supposed to increase the plasma cholesterol content of animals without changing the rate of absorption or excretion of cholesterol $(3,5,11,18,27)$. Rosenman, Byers and Friedman have observed a moderate reduction in the rate of hepatic synthesis of cholesterol during pregnancy though the plasma cholesterol content was not changed. The same has been found in estrogen treated rats (7). 
In brief, it would appear that the large variations observed in the plasma cholesterol content of normal dairy cows are primarily due to the variations in the liver functions in different stages of production and on different type of feeding.

\section{The effect of feeding}

As reported erlier on the basis of 4 feeding trials comprising 9 groups and 61 cows (23) 1) there is a fairly high correlation between the plasma cholesterol content and the level of milk and fat yield $(\mathrm{r}=+0.642$ and $\mathrm{r}=+0.544$ respectively) and, 2) a slightly less significant correlation between the plasma cholesterol content on the one hand and the stage of lactation and/or pregnancy on the other, 3) the plasma cholesterol content is influenced by the feeding and primarily by the amount of net energy and digestible crude fat in the ration and 4) the plasma cholesterol values of barren cows possibly differ from those of normal cows.

Since this work was published in 1944 very little of new information about the effects of the diet on plasma cholesterol in domestic animals has been presented. In regard to the humans, however, very comprehensive studies have been published recently by Keys $(15,16)$. Some of these results, which in general are very much in accord with the author's observations mentioned above, may be cited here too.

1) The cholesterol content of the diet is, in itself of little or no interest to man in all practical situations. And the distinction between animal and vegetable fat is not of peculiar importance.

2) The major dietary factor which affects the serum cholesterol level is the total fat or the proportion of calories supplied by all fat metabolism.

3) Beyond the first two decades of life the human body becomes increasingly sensitive to dietary influences in cholesterol metabolism. If the habitual diet is luxurious, rich in fats and abundant or excessive in calories, the serum cholesterol level tends to rise progressively with age until the mode of life and/or the aging process itself forces a change.

4) Chronic undernutrition may reduce the serum cholesterol to low levels.

When investigating the effect of feeding on volatile fatty acids in cow's blood plasma it was observed by the author (25) that the amount of digestible crude fiber in the ration showed a positive correlation with the content of blood v.f.a., which, as mentioned before, can be utilized as precursors of plasma cholesterol. It was noticed also, that there was possibly a relationship between the level of digestible protein in the ration and the plasma cholesterol content (see. fig. 3).

In short, it would then appear that there are several factors simultaneously affecting the plasma cholesterol content of normal cows. When investigating the dietary influences the effects of several physiological factors must also be taken into consideration. At the time this study was initiated the following factors seemed to be particularly worth investigating.

1) The level of net energy intake,

2) The level of protein intake, 
3) The amount of fat in the ration,

4) The amount of crude fiber in the ration,

5) The level of milk yield and/or net energy requirement,

6) The stage of lactation and/or pregnancy,

7) Age and

8) Barreness (functional disorders).

\section{Experimental procedure}

According to the original schedule of this study the dietary factors listed above were to be investigated separately, using feeding trials and a combined group and period test method. The cows were kept on constant feeding until the plasma cholesterol values were stabilized (for two weeks at least). Then after taking the blood samples, each variable in the ration one after the other was changed, while simultaneously the other factors under experiment were supposed to be kept constant. Cows of different age, and in different stages of lactation, normal and barren, were used in this study.

The feeding trials were conducted during the stall-feeding periods. All of the cows were fed individually. Low, normal and high planes of nutrition were used. The amount of fat in the ration was changed mainly by using variable amounts of linseed, which was heated until about $105^{\circ} \mathrm{C}$ and crushed after heating. Different concentrates and different roughages were used. Description of the feeds their chemical composition, assumed coefficients of digestibility and the calculated net energy values plus the amounts of the feed used in the rations in each trial are presented in table 1 .

The net energy values of the feeds were calculated in Scandinavian feed units assuming that one Sc.fu. corresponds to 0.704 Starch equivalent of Kellner or 1660 calories net energy for fattening. In calculating the net energy requirement Poijärvi's (20) standards were used. The protein standards used in the calculations were $100 \mathrm{~g}$ of digestible crude protein per every feed unit for maintenance, $150 \mathrm{~g}$ per feed unit for milk production and $50 \mathrm{~g}$ per feed unit for fattening.

The cows were fed and milked twice daily. Milking was done by machine. In the beginning composite milk samples were taken for 2 consecutive days every 5 days. Later, composite 3 -day samples were taken for each consecutive 3-day period.

The blood samples were taken from the middle artery of the tail (A. coccygea) using the technique described previously by the author (22). The cholesterol in the blood plasma was determined colorimetrically by Saarinen's extraction method $(23,24)$. The Gerber procedure was used for determining milk fat. A regular feed analysis was made of all feeds used. All determinations were run in duplicate at least.

In the first trials conducted in accordance with the original scheme very high correlations between the dietic factors and the plasma cholesterol content were observed. The regression were, however, different in different trials. This was due to the fact that the plasma cholesterol content is always a resultant of several factors that inevitably vary during the trial. For example the stage of lactation, milk yield 


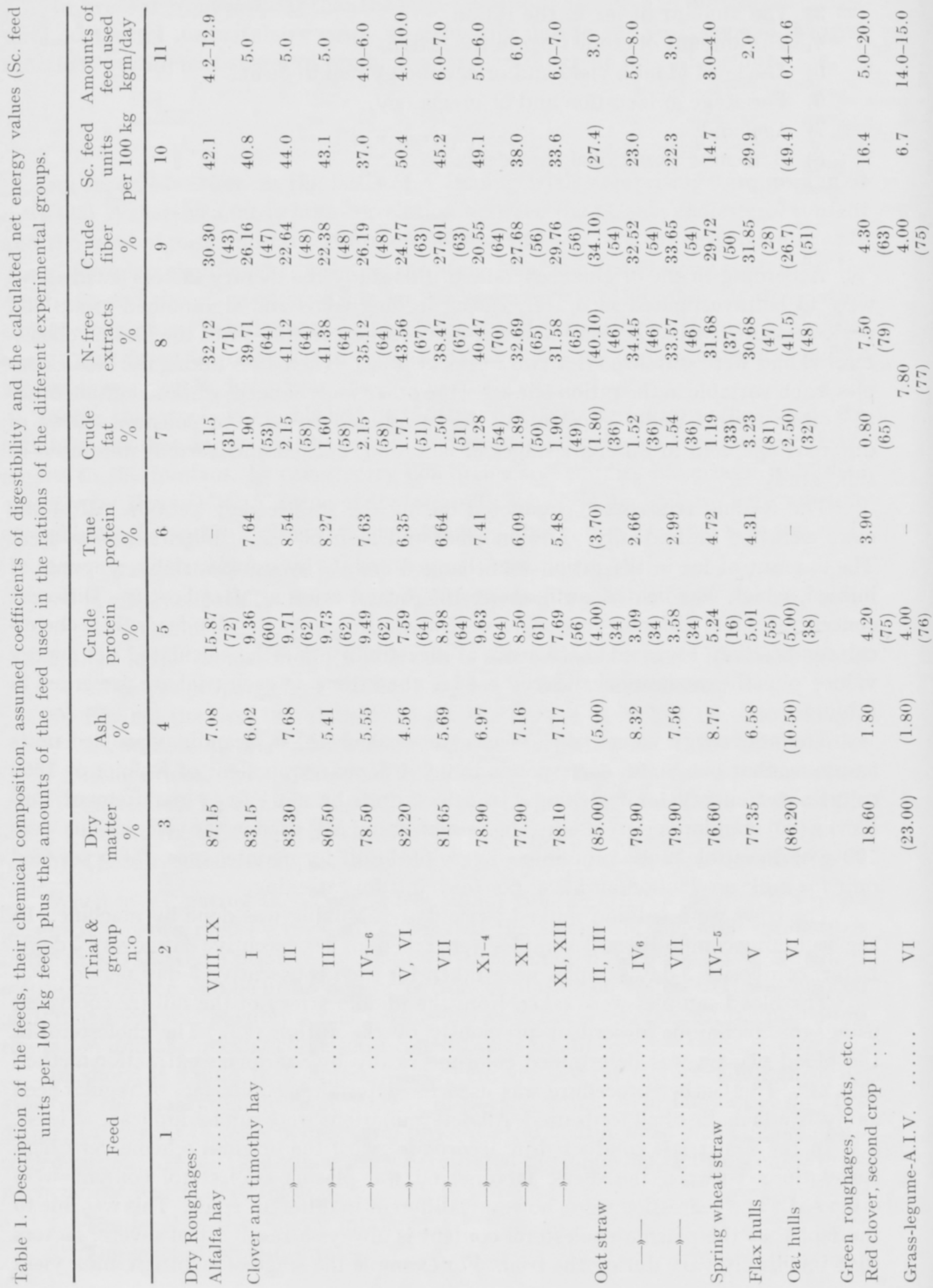




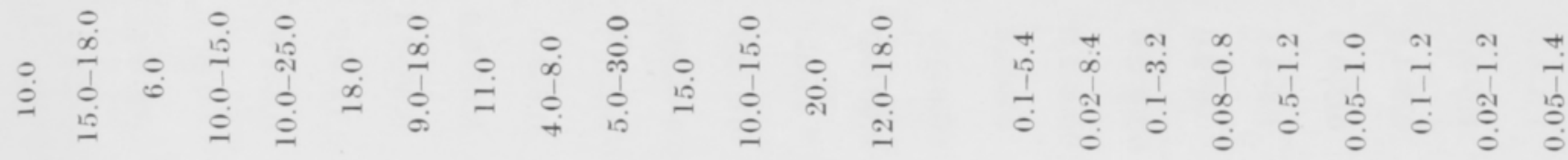

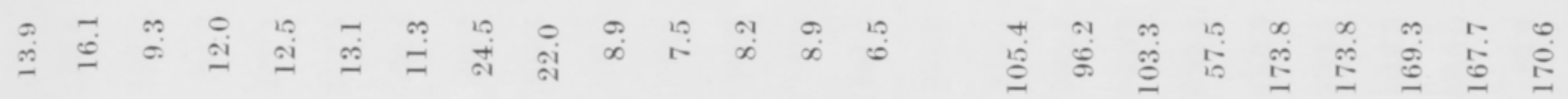

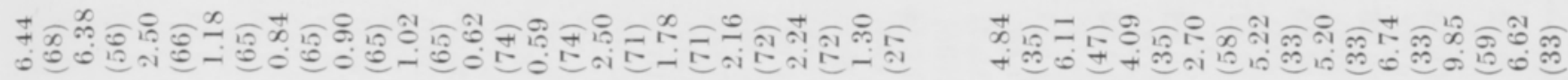

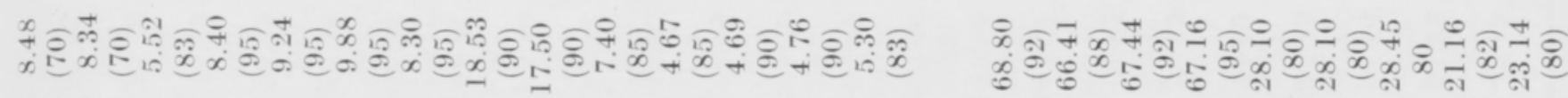

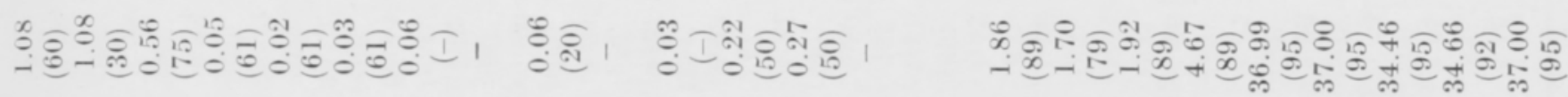

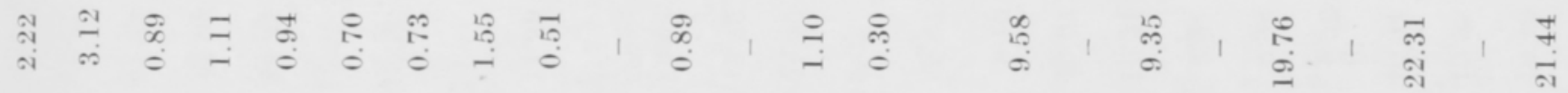

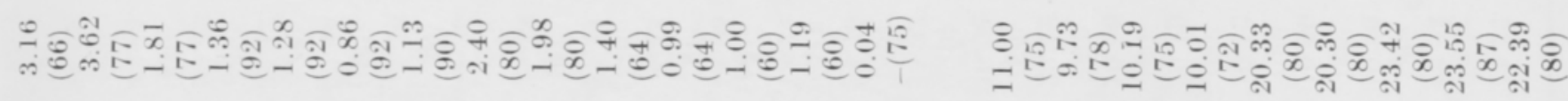

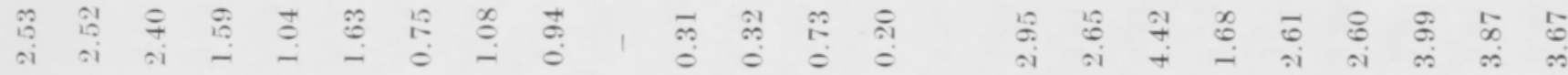

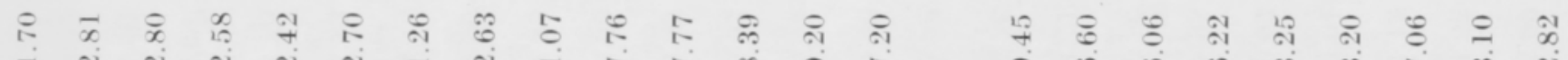

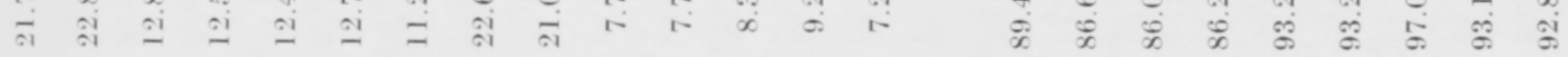

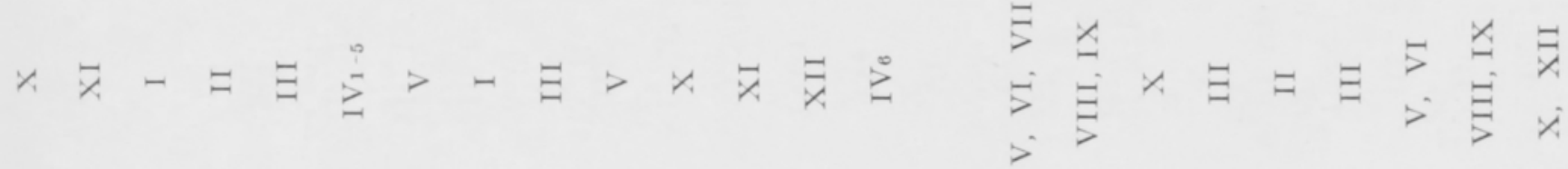

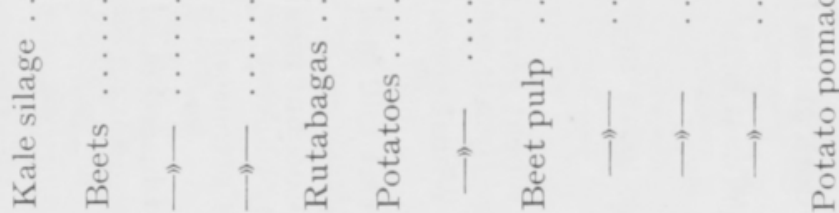




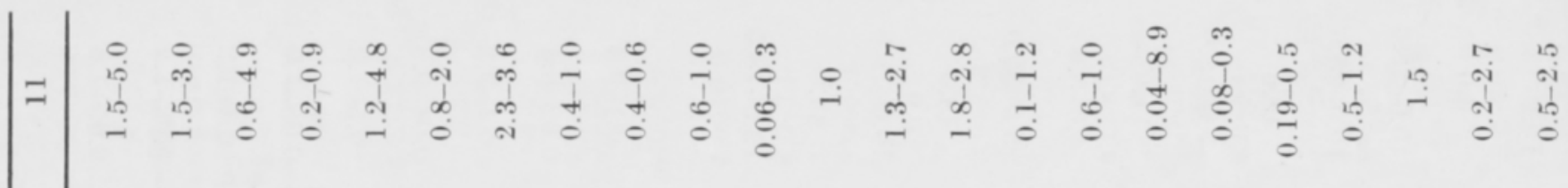

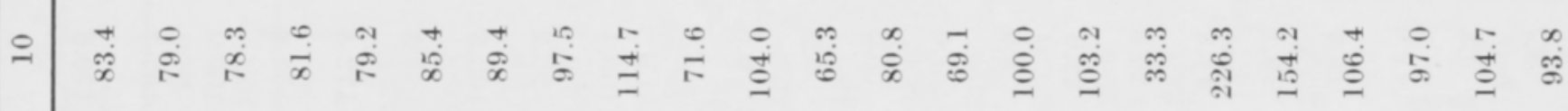

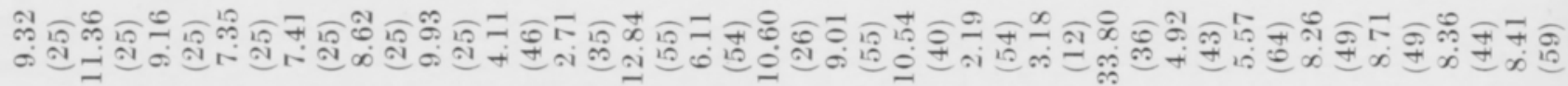

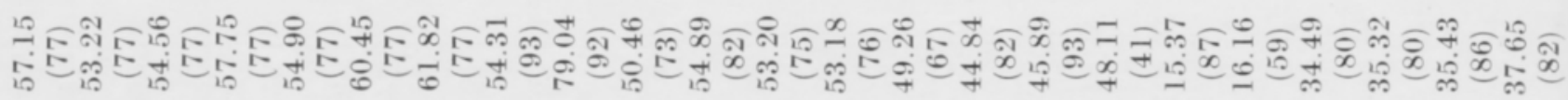

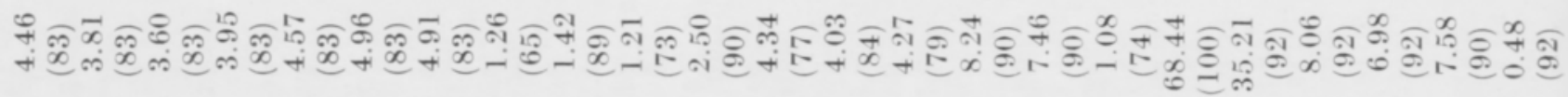

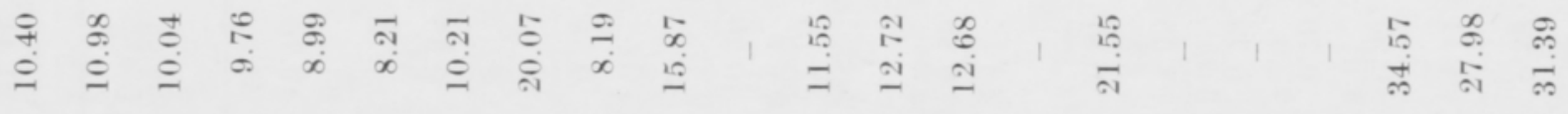

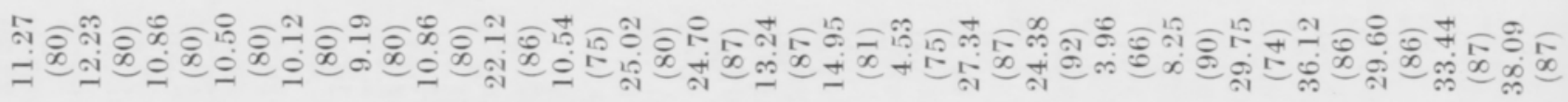

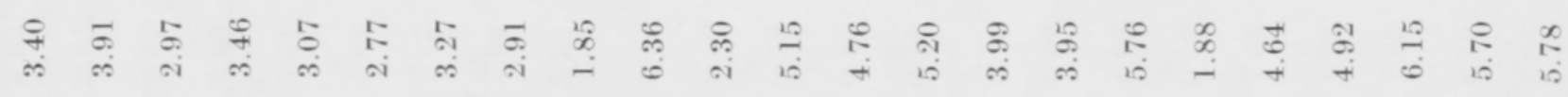

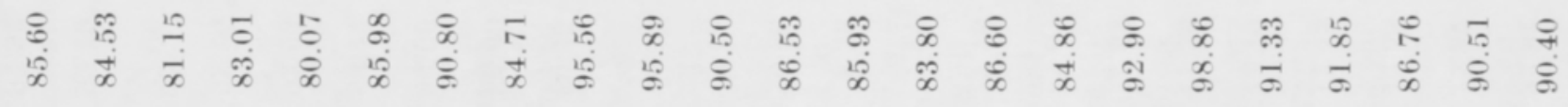

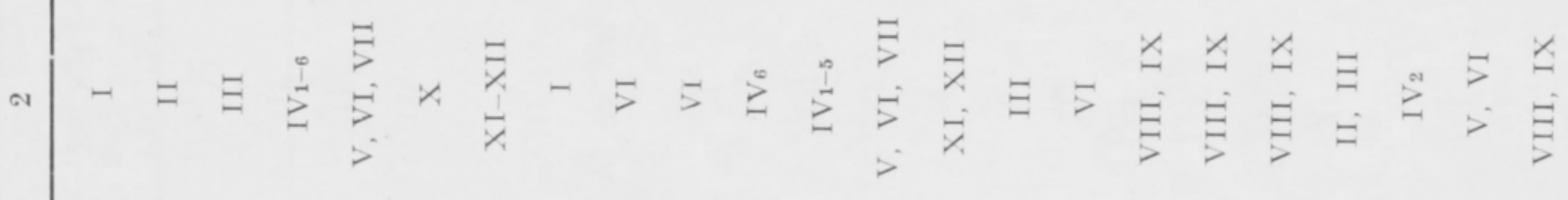

$$
\begin{aligned}
& -
\end{aligned}
$$

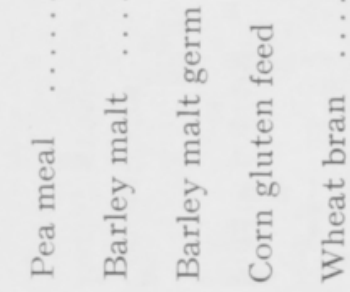

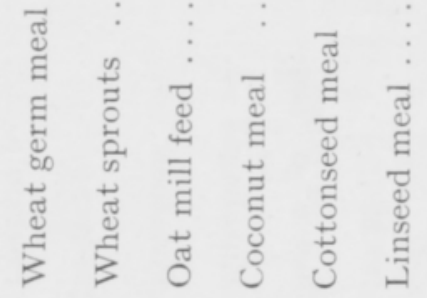




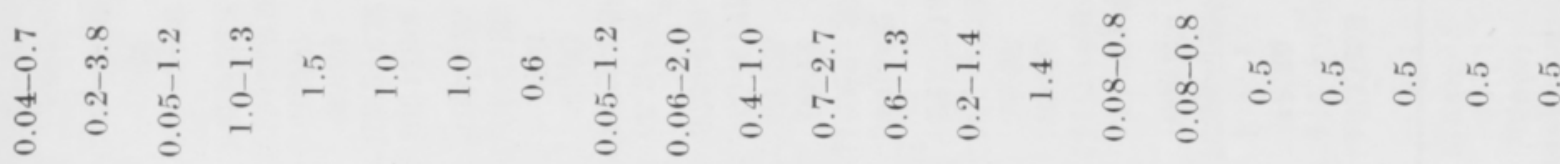

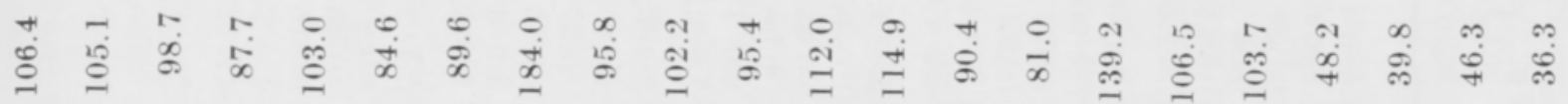

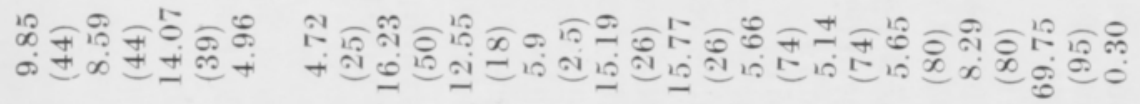

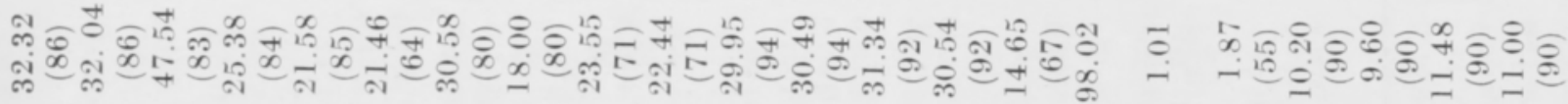

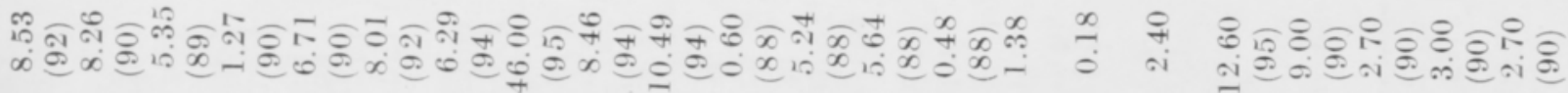

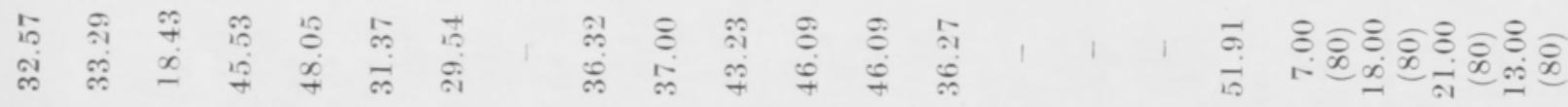

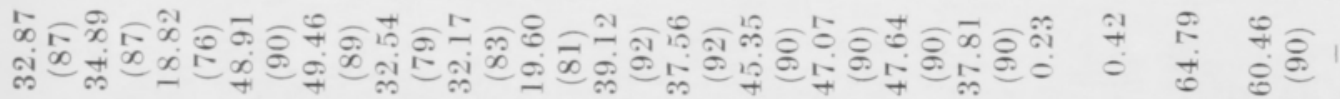

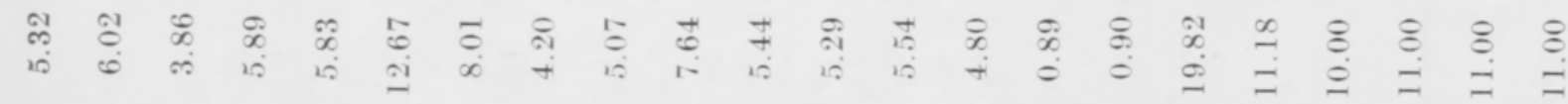

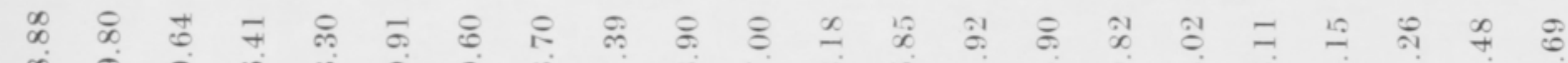

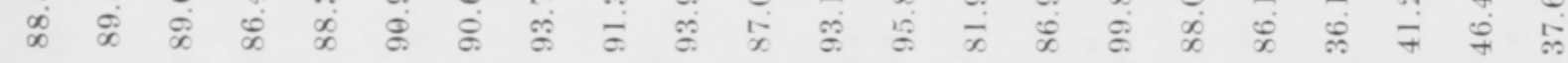

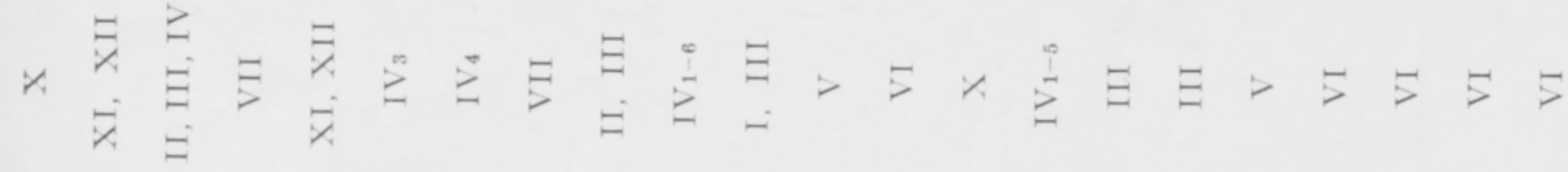




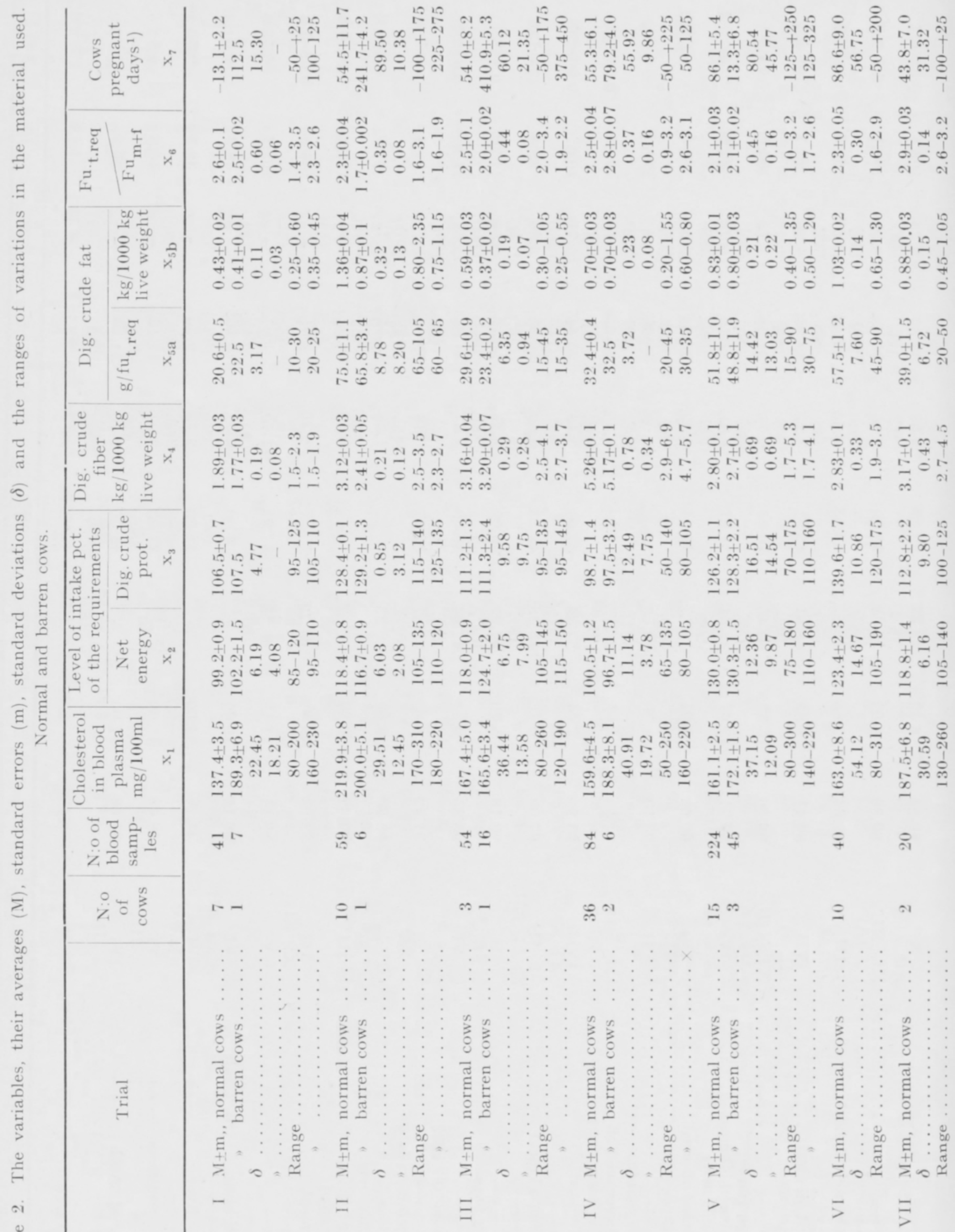




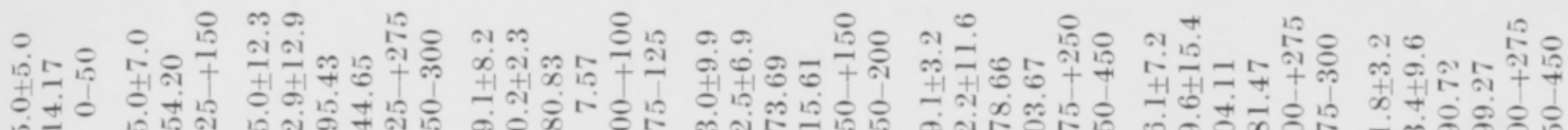
过 - 18 응 ำำ

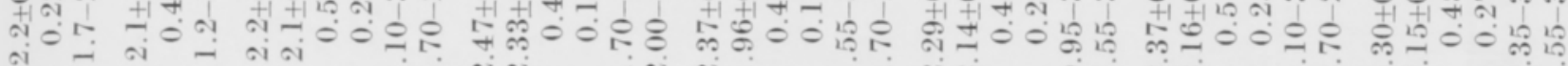

ติ ติ

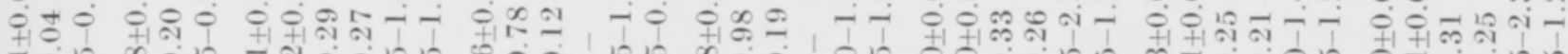

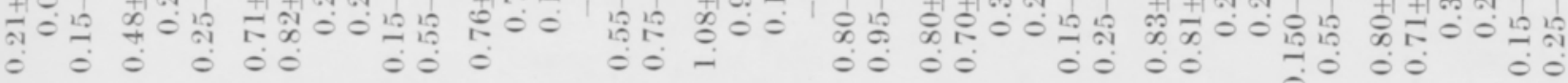

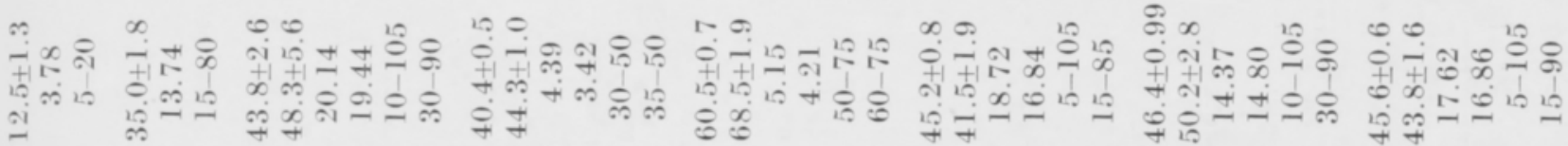
定 ต $M$ -

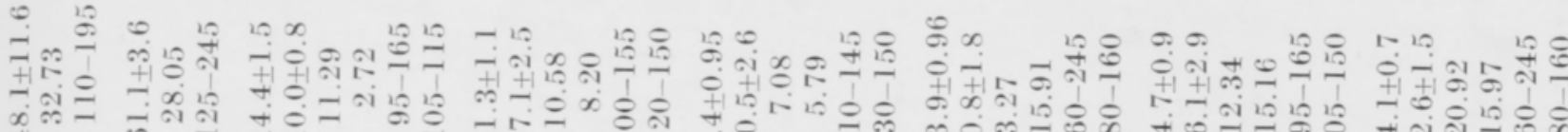
更 mô ๑)

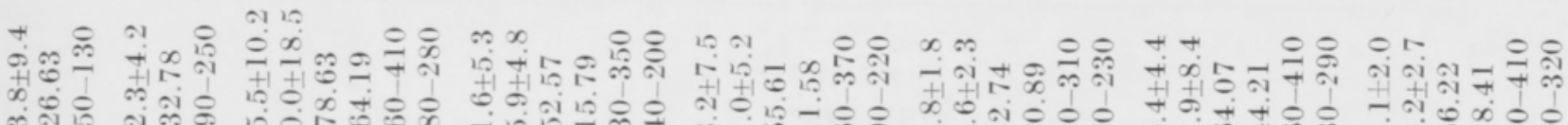

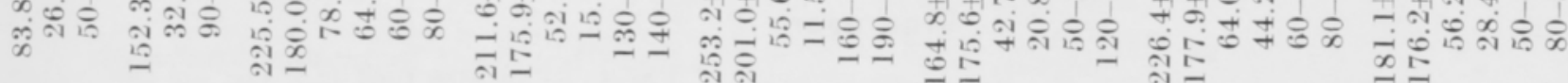

\begin{tabular}{|c|c|c|c|c|c|}
\hline 8 & 8. & $5=$ & 1020 & $\stackrel{8}{8}$ & $\underset{\mathrm{N}}{\mathrm{N}} \infty$ \\
\hline 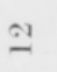 & $\varrho .1$ & $0-$ & $=-$ & $g \infty$ & $\ddot{\infty}^{+}$ \\
\hline
\end{tabular}

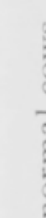
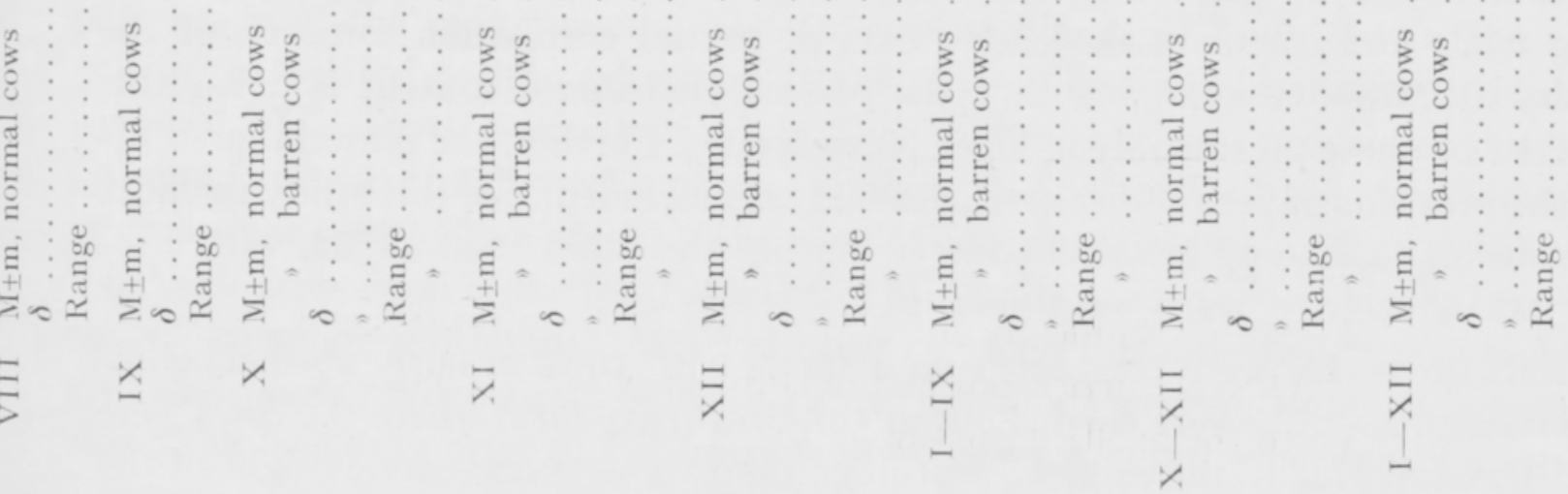


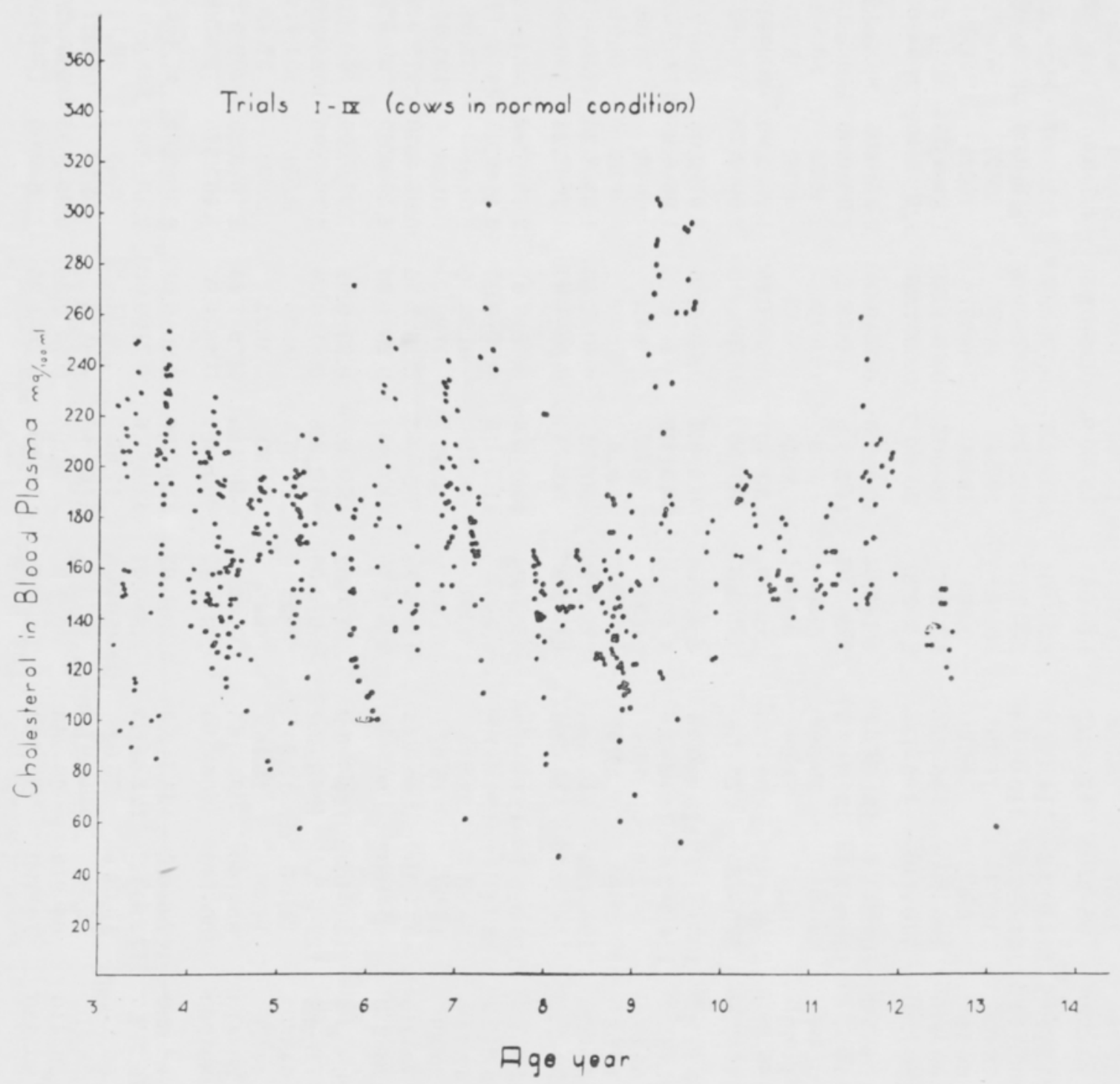

Fig. 1. The effect of the age on the

and energy requirements always vary to some extent, and so do also the proportional level of feeding, protein intake etc. indirectly if the ration is kept unchanged. When the influences of the individual variates were unknown, neither could the feeding be adjusted so, that the experimental results showed the true effects of the individual dietic factors. So, it deemed to be advisable to combine the material of different feeding trials and calculate the coefficients of partial correlation for each of the variables listed above assuming that the plasma cholesterol content is a variable dependent on these presumably independent variates. Further, the material presented in the previous paper (23) was recalculated and included. So, this study includes the results of 12 feeding trials conducted during the years 1939-1952, with altogether 141 Ayrshire cows.

Trials no I-IX were conducted on 3 farms with cows in fairly normal condition. Trials no X-XII were carried out at the University farm where the cows were fairly fat mainly due to the exellent pasturage there. The average live weight of the 


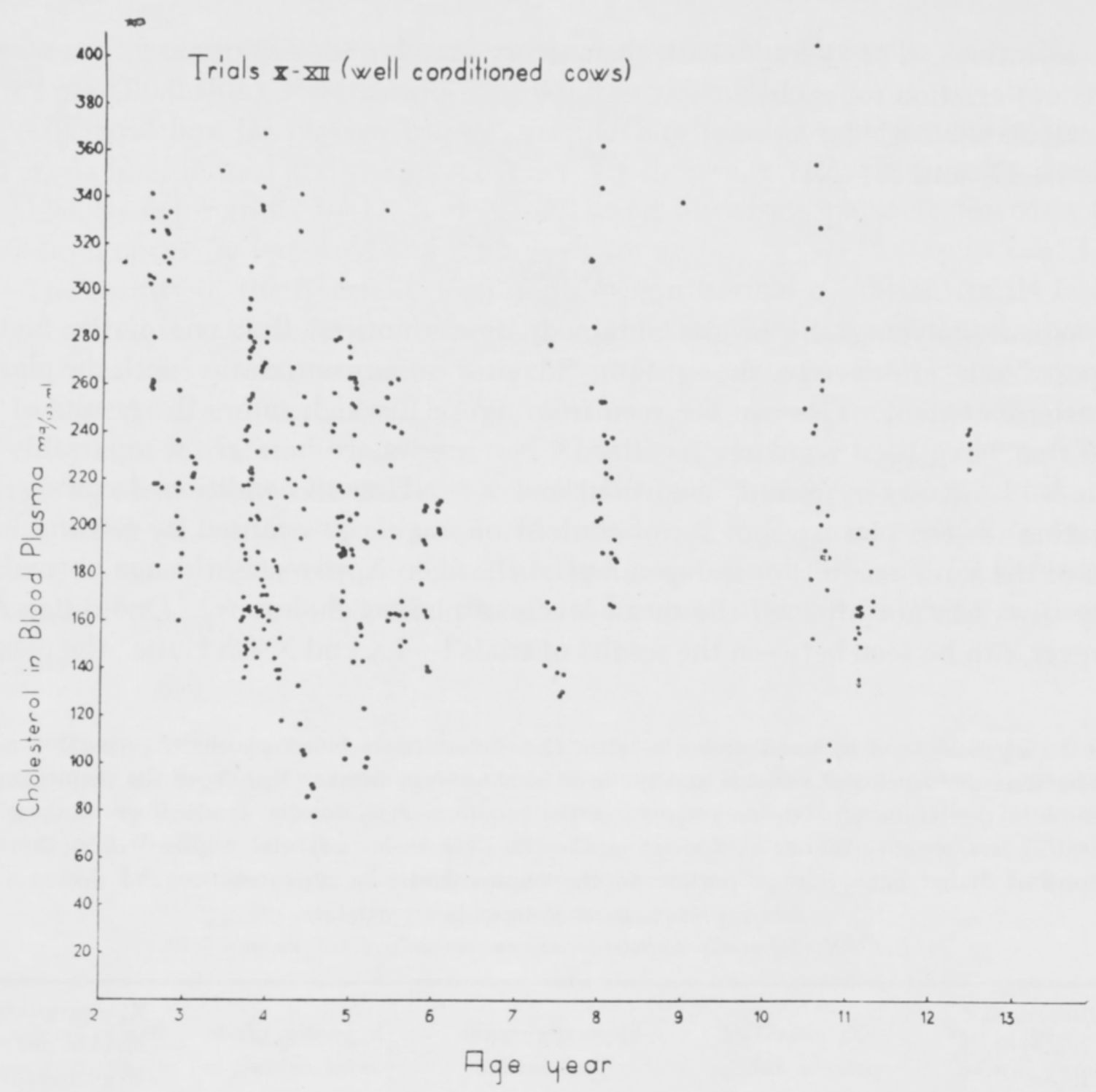

cholesterol content of the blood plasma.

cows in trials I- IX was $462 \mathrm{~kg}$ and in trials X-XII $507 \mathrm{~kg}$. Due to this inequality of the experimental animals and the somewhat different results obtained, the results for trials I-IX and X-XII have been calculated separately. In both cases the results for normal and barren cows were also treated separately.

The levels of net energy intake $\left(\mathrm{x}_{2}\right)$ and protein intake $\left(\mathrm{x}_{3}\right)$ were calculated as a percentage of the requirements. The amount of digestible crude fat in the ration $\left(\mathrm{X}_{4}\right)$ was calculated both in grams per $1000 \mathrm{~kg}$ live weight and in grams per feed unit required. The actual amount of crude fiber rather than any proportional amount appeared to be correlated with plasma cholesterol and this $\left(\mathrm{x}_{5}\right)$ was calculated only in grams per $1000 \mathrm{~kg}$ live weight. The level of net energy requirement $\left(\mathrm{x}_{6}\right)$ was calculated as a proportion of the total amount of feed units needed to the amount required for maintenance and foetus. As a indicator common for both the stage of lactation and the stage of pregnancy a value $\left(\mathrm{x}_{7}\right)$ »days pregnant» has been used. In calculating this value the days prior to fertilization have been taken into consideration as nega- 
tive deviations. The averages with their errors, standard deviations and the extreme limits of variation for each of these variables are presented in table 2 . These values are calculated both for normal and barren cows in every trial and separately for trials I-IX and X-XII.

\section{Results}

When analyzing the results obtained, it was noticed that one of the factors supposed to be effective i.e. the age (16), did not show any correlation with the plasma cholesterol content. This can bee seen from figure 1, which shows the results of the cows that have been regularly fertilized. The results are here given separately for trials I-IX (cows in normal condition) and X-XII (well conditioned cows). The variations in the plasma cholesterol content of single cows caused by feeding have been of the same magnitude independent of the age. Apparently the age normal for dairy cows has not affected the mean levels of plasma cholesterol. One difference, however, can be seen between the results of trials I-IX and X-XII, i.e., the plasma

Table 3. Coefficients of partial correlation when the cholesterol in blood plasma $\left(\mathrm{X}_{1}=\mathrm{mg} / 100 \mathrm{ml}\right)$ is considered as the dependent variable and the level of net energy intake $\left(\mathrm{X}_{2}=\%\right.$ of the requirements), the level of dig. crude prot. intake $\left(\mathrm{X}_{3}=\%\right.$ of the requirements), the dig. crude fiber intake $\left(\mathrm{X}_{4}=\right.$ $\mathrm{kg} / 1000 \mathrm{~kg}$ live weight), the dig. crude fat intake $\left(\mathrm{X}_{5 \mathrm{a}}=\mathrm{g} / \mathrm{feed}\right.$ unit total required) and the total requirement of net energy in proportion to the requirements for maintenance and foetus $\left(\mathrm{X}_{6}=\right.$ $\mathrm{fu} \cdot \mathrm{t}$.req. $/ \mathrm{fu} \cdot \mathrm{m}+\mathrm{f})$ as independent variables.

Trials $I-I X$. Normally fertilized cows in normal condition, $(n=590)$.

$\begin{array}{cccc}\mathrm{X}_{2}=\text { level of net } & \mathrm{X}_{3}=\text { level of } & \mathrm{X}_{4}=\text { dig. crude } & \mathrm{X}_{5 \mathrm{a}}=\text { dig. crude } \\ \text { energy intake } & \text { protein intake } & \text { fiber intake } & \text { fat intake }\end{array}$

$\mathrm{X}_{6}=$ proportional level of net ener-

gy required

\begin{tabular}{|c|c|c|c|c|c|c|c|c|c|}
\hline $\mathrm{r}_{12}$ & $=+0.0352$ & $\mathrm{r}_{13}$ & $=+0.0341$ & $\mathrm{r}_{14}$ & $=+0.1486$ & $\mathrm{r}_{15}$ & $=+0.4444$ & $\mathrm{r}_{16}$ & $=+0.3726$ \\
\hline $\mathrm{r}_{12 ; 3}$ & $=+0.0154$ & $\mathrm{r}_{13 ; 2}$ & $=+0.0127$ & $\mathrm{r}_{14 ; 2}$ & $=+0.1551$ & $\mathrm{r}_{15 ; 2}$ & $=+0.4553$ & $\mathrm{r}_{16 ; 2}$ & $=+0.3963$ \\
\hline $\mathrm{r}_{12 ; 4}$ & $=+0.0572$ & $\mathrm{r}_{13 ; 4}$ & $=+0.0705$ & $\mathrm{r}_{14 ; 3}$ & $=+0.1607$ & $r_{15 ; 3}$ & $=+0.4626$ & $\mathrm{r}_{16 ; 3}$ & $=+0$. \\
\hline$r_{12 ; 5}$ & $=-0.1159$ & ${ }^{\mathrm{r}} 13 ; 5$ & $=-0.1474$ & $\mathrm{r}_{14 ; 5}$ & $=+0.2748$ & $\mathrm{r}_{15 ; 4}$ & $=+0.4912$ & $\mathrm{r}_{16 ; 4}$ & $=+0.3490$ \\
\hline $\mathrm{r}_{12 ; 6}$ & $=+0.1498$ & $\mathrm{r}_{13 ; 6}$ & $=+0.2536$ & $\mathrm{r}_{14 ; 6}$ & $=+0.0521$ & $r_{15 ; 6}$ & $=+0.6191$ & $\mathrm{r}_{16 ; 5}$ & $=+0.5815$ \\
\hline $\mathrm{r}_{12 ; 34}$ & $=+0.0099$ & $\mathrm{r}_{13 ; 24}$ & $=+0.0425$ & $\mathrm{r}_{14 ; 23}$ & $=+0.1602$ & $\mathrm{r}_{15 ; 23}$ & $=+0.4628$ & $\mathrm{r}_{16 ; 23}$ & $=+0.4407$ \\
\hline $\mathrm{r}_{12 ; 35}$ & $=-0.0206$ & $\mathrm{r}_{13 ; 25}$ & $=-0.0939$ & $\mathrm{r}_{14 ; 25}$ & $=+0.2679$ & $r_{15 ; 24}$ & $=+0.4960$ & $\mathrm{r}_{16 ; 24}$ & $=+0.3739$ \\
\hline $\mathrm{r}_{12 ; 36}$ & $=-0.0391$ & $\mathrm{r}_{13 ; 26}$ & $=+0.2105$ & $\mathrm{r}_{14 ; 26}$ & $=+0.0639$ & $r_{1526}$ & $=+0.6076$ & $r_{16 ; 25}$ & $=+0.5737$ \\
\hline $\mathrm{r}_{12 ; 45}$ & $=-0.0972$ & $\mathrm{r}_{13 ; 45}$ & $=-0.1067$ & $\mathrm{r}_{14 ; 35}$ & $=+0.2564$ & $r_{15 ; 34}$ & $=+0.4962$ & $r_{16 ; 34}$ & $=+0.4218$ \\
\hline $\mathrm{r}_{12 ; 46}$ & $=+0.1541$ & $\mathrm{r}_{13 ; 46}$ & $=+0.2618$ & $\mathrm{r}_{14 ; 36}$ & $=+0.0852$ & $\mathrm{r}_{15 ; 36}$ & $=+0.5920$ & $\mathrm{r}_{16 ; 35}$ & $=+0.5773$ \\
\hline $\mathrm{r}_{12 ; 56}$ & $=-0.0025$ & $\mathrm{r}_{13 ; 56}$ & $=+0.1212$ & $\mathrm{r}_{14 ; 56}$ & $=+0.1796$ & $r_{15 ; 46}$ & $=+0.6335$ & $\mathrm{r}_{16 ; 45}$ & $=+0$. \\
\hline$r_{12 ; 345}$ & $=-0.0335$ & $\mathrm{r}_{13 ; 245}$ & $=+0.1550$ & $\mathrm{r}_{14 ; 235}$ & $=+\mathrm{p} .2576$ & $r_{15 ; 234}$ & $=+0.4970$ & $\mathrm{r}_{16 ; 234}$ & $=+0.4336$ \\
\hline $\mathrm{r}_{12 ; 346}$ & $=-0.0109$ & $\mathrm{r}_{13 ; 246}$ & $=+0.2178$ & $\mathrm{r}_{14 ; 236}$ & $=+0.1343$ & $r_{15 ; 236}$ & $=+0.5985$ & $\mathrm{r}_{16}$ & $=+0.5847$ \\
\hline $\mathrm{r}_{12 ; 356}$ & $=-0.1157$ & $\mathrm{r}_{13 ; 256}$ & $=+0.1668$ & $\mathrm{r}_{14 ; 256}$ & $=+0.1788$ & $r_{15 ; 246}$ & $=+0.6218$ & $r_{16 ; 245}$ & $=+0.5480$ \\
\hline $\mathrm{r}_{12 ; 456}$ & $=+0.0046$ & $\mathrm{r}_{13 ; 456}$ & $=+0.1389$ & $\mathrm{r}_{14 ; 356}$ & $=+0.1911$ & $r_{15 ; 346}$ & $=+0.6081$ & $r_{16 ; 345}$ & $=+0.5592$ \\
\hline $\mathrm{r}_{12 ; 3456}$ & $=-0.0790$ & $\mathrm{r}_{13 ; 2456}$ & $=+0.5210$ & ${ }^{r} 14 ; 2356$ & $=+0.2675$ & $\mathrm{r}_{15 ; 2346}$ & $=+0.6248$ & $\mathrm{r}_{16 ; 2345}$ & $=+0.5874$ \\
\hline
\end{tabular}

$\mathrm{X}_{1}=-0.21 \cdot \mathrm{X}_{2}+1.13 \cdot \mathrm{X}_{3}+7.95 \cdot \mathrm{X}_{4}+1.39 \cdot \mathrm{X}_{5}+0.51 \cdot \mathrm{X}_{6}-155.8$

or approximately $\mathrm{X}_{1}=5.46 \cdot \mathrm{X}_{4}+1.41 \cdot \mathrm{X}_{5}+0.45 \cdot \mathrm{X}_{6}-19.0$. 
cholesterol content has been on an average appreciably higher in trials $\mathrm{X}$-XII $(226.4 \mathrm{mg} / 100 \mathrm{ml})$ than in trials I-IX $(164.8 \mathrm{mg} / 100 \mathrm{ml})$.

The results of the variates $\mathrm{x}_{2}-\mathrm{x}_{6}$ (the level of energy and protein intake, fat and crude fiber in feed and the level of energy requirement) are presented separately in tables 3-6 for trials I-IX and X-XII and likewise separately for cows that have been normally fertilized and for barren cows.

The results of the normally fertilized cows in normal condition (trials I-IX) are presented in table 3 . It can be seen from here that the plasma cholesterol content $\left(\mathrm{x}_{1}\right)$ shows a fairly high correlation with the proportional level of net energy required $\left(\mathrm{x}_{6}\right)$ when the simultaneous effects of variates $\mathrm{x}_{2}-\mathrm{x}_{5}$ are also eliminated. Due to a fairly high correlation between the variates $x_{6}$ and $x_{7}\left(r_{67 ; 2345}=-0.7386\right)$ variate $\mathrm{x}_{6}$ when used alone partially reveals the combined effects of $\mathrm{x}_{6}$ and $\mathrm{x}_{7}$. The actual effect of variate $x_{6}$ is, however, dominating $\left(\mathrm{r}_{16 ; 23457}=-0.5534\right)$ so, e.g. variate $x_{7}$, when used instead of the variate $x_{6}$, has shown a negative coefficient of correlation $\left(\mathrm{r}_{17 ; 2345}=-0.3040\right)$, though the actual effect appears to be positive $\left(\mathrm{r}_{17 ; 23456}=+0.2380\right)$.

Table 4. Coefficients of partial correlation when the cholesterol in blood plasma $\left(\mathrm{X}_{1}=\mathrm{mg} / 100 \mathrm{ml}\right)$ is considered as the dependent variable and the level of net energy intake $\left(\mathrm{X}_{2}=\%\right.$ of the requirements), the level of dig. crude prot. intake $\left(\mathrm{X}_{3}=\%\right.$ of the requirements), the dig. crude fiber intake $\left(\mathrm{X}_{4}=\right.$ $\mathrm{kg} / 1000 \mathrm{~kg}$ live weight), the dig. crude fat intake $\left(\mathrm{X}_{5 \mathrm{a}}=\mathrm{g} / \mathrm{feed}\right.$ unit total required $)$, and the total requirement of net energy in proportion to the requirements for maintenance and foetus $\left(\mathrm{X}_{6}=\right.$ $\mathrm{fu} \cdot{ }_{\text {t.req. }}(\mathrm{fu} \cdot \mathrm{m}+\mathrm{f})$ as independent variables.

Trials $I-I X$. Barren cows in normal condition $(n=108)$.

\begin{tabular}{|c|c|c|c|c|}
\hline $\begin{array}{l}\mathrm{X}_{2}=\text { level of net } \\
\text { energy intake }\end{array}$ & $\begin{array}{c}\mathrm{X}_{3}=\text { level of } \\
\text { protein intake }\end{array}$ & $\begin{array}{l}\mathrm{X}_{4}=\text { dig. crude } \\
\text { fiber intake }\end{array}$ & $\begin{array}{c}\mathrm{X}_{5 \mathrm{a}}=\text { dig. crude } \\
\text { fat intake }\end{array}$ & $\begin{array}{l}\mathrm{X}_{6}=\text { proportional } \\
\text { level of net ener- } \\
\text { gy required }\end{array}$ \\
\hline
\end{tabular}

\begin{tabular}{|c|c|c|c|c|c|c|c|c|c|}
\hline 12 & $=-0.0675$ & $\mathrm{r}_{13}$ & $=+0.1744$ & ${ }^{\mathrm{r}}{ }_{14}$ & $=+0.1375$ & $\mathrm{r}_{15}$ & $=+0.2878$ & ${ }^{\mathrm{r}}{ }_{16}$ & +7 \\
\hline $12 ; 3$ & $=-0.1821$ & $\mathrm{r}_{13 ; 2}$ & $=+0.2414$ & $\mathrm{r}_{14 ; 2}$ & $=+0.1295$ & $\mathrm{r}_{15 ; 2}$ & $=+0.3076$ & $\mathrm{r}_{16 ; 2}$ & 326 \\
\hline 2,4 & $=-0.0489$ & $\mathrm{r}_{13 ; 4}$ & $=+0.1810$ & $\mathrm{r}_{14 ; 3}$ & $=+0.1459$ & $\mathrm{r}_{15 ; 3}$ & $=+0.2381$ & $r_{16 ; 3}$ & 432 \\
\hline $2 ; 5$ & $=-0.1318$ & $\mathrm{r}_{13 ; 5}$ & $=+0.0525$ & $\mathrm{r}_{14 ; 5}$ & $=+0.1708$ & $\mathrm{r}_{15 ; 4}$ & $=+0.3041$ & ${ }^{r}{ }_{16 ; 4}$ & 81 \\
\hline $2 ; 6$ & $=+0.0311$ & $\mathrm{r}_{13 ; 6}$ & $=+0.2609$ & $\mathrm{r}_{14 ; 6}$ & $=+0.0972$ & $\mathrm{r}_{15 ; 6}$ & $=+0.3809$ & $\mathrm{r}_{16 ; 5}$ & $=t$ \\
\hline $2 ; 34$ & $=-0.1$ & $\mathrm{r}_{13 ; 24}$ & $=+0.2381$ & $\mathrm{r}_{14 ; 23}$ & $=+0.1229$ & $\mathrm{r}_{15 ; 23}$ & $=+0.2350$ & $\mathrm{r}_{16 ; 23}$ & \\
\hline $2 ; 35$ & $=-0.1$ & $\mathrm{r}_{13 ; 25}$ & $=+0.1$ & $\mathrm{r}_{14 ; 25}$ & $=+1$ & $\mathrm{r}_{15 ; 24}$ & $=+$ & $\mathrm{r}_{16}$ & \\
\hline $2 ; 36$ & $=-0.0646$ & $\mathrm{r}_{13 ; 26}$ & $=+0.2664$ & $\mathrm{r}_{14 ; 26}$ & $=+\theta$ & $\mathrm{r}_{15}$ & $=+$ & $\mathrm{r}_{16}$ & \\
\hline $8 ; 45$ & $=-0.1125$ & $\mathrm{r}_{12 ; 45}$ & $=-0$. & ${ }^{r} 14 ; 35$ & $=+c$ & $\mathrm{r}_{15}$ & $=+$ & $\mathrm{r}_{16}$ & $=$. \\
\hline $12 ; 46$ & $=+0.0235$ & $\mathrm{r}_{13 ; 46}$ & $=+0$. & ${ }^{\mathrm{r}} 14 ; 36$ & $=+0$ & $\mathrm{r}_{15}$ & $=+c$ & $\mathrm{r}_{1}$ & $=$ - \\
\hline $12 ; 56$ & $=+0.0653$ & $\mathrm{r}_{13 ; 56}$ & $=+0.1509$ & $\mathrm{r}_{14 ; 56}$ & $=+0$ & & $=+1$ & $\mathrm{r}_{16}$ & $=+$ \\
\hline $12 ; 345$ & $=-0.1$ & $\mathrm{r}_{12 ; 245}$ & $=+0.1215$ & $\mathrm{r}_{14 ; 235}$ & $=+0$ & $\mathrm{r}_{15 ; 234}$ & $=+0$ & $\mathrm{r}_{16 ; 234}$ & $=+$ \\
\hline $12 ; 346$ & $=-0.08$ & $\mathrm{r}_{13 ; 246}$ & $=+0.2599$ & $\mathrm{r}_{14 ; 236}$ & $=+0.0735$ & & $=+0$ & & $=+1$ \\
\hline $12 ; 356$ & $=+0.00$ & $\mathrm{r}_{13 ; 256}$ & $=+0$ & $\mathrm{r}_{14 ; 256}$ & $=+0.0820$ & $\mathrm{r}_{15}$ & $=+$ & & $=+c$ \\
\hline & $=+0.0586$ & $r_{13 ; 456}$ & $=+0.0293$ & $\mathrm{r}_{14}$ & $=+1$ & & $=+0$ & & $=+0$ \\
\hline 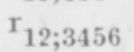 & $=+00038$ & $\mathrm{r}_{13 ; 2456}$ & $=+0$ & $\mathrm{r}_{14 ; 2356}$ & $=+0$. & 2346 & $=+1$ & $r_{16 ; 2345}$ & . \\
\hline
\end{tabular}


Table 5. Coefficients of partial correlation when the cholesterol in blood plasma $\left(\mathrm{X}_{1}=\mathrm{mg} / 100 \mathrm{ml}\right)$ is considered as the dependent variable and the level of net energy intake $\left(\mathrm{X}_{2}=\%\right.$ of the requirements), the level of dig. crude prot. intake $\left(\mathrm{X}_{3}=\%\right.$ of the requirements), the dig. crude fiber intake $\left(\mathrm{X}_{4}=\right.$ $\mathrm{kg} / 1000 \mathrm{~kg}$ live weight), the dig. crude fat intake $\left(\mathrm{X}_{5 \mathrm{a}}=\mathrm{g} / \mathrm{feed}\right.$ unit total required $)$ and the total requirement of net energy in proportion to the requirements for maintenance and foetus $\left(\mathrm{X}_{6}=\right.$ $\mathrm{fu}$.t.req. $(\mathrm{fu} \cdot \mathrm{m}+\mathrm{f})$ as independent variables.

Trials $X-X I I$. Well conditioned normally fertilized cows $(n=212)$.

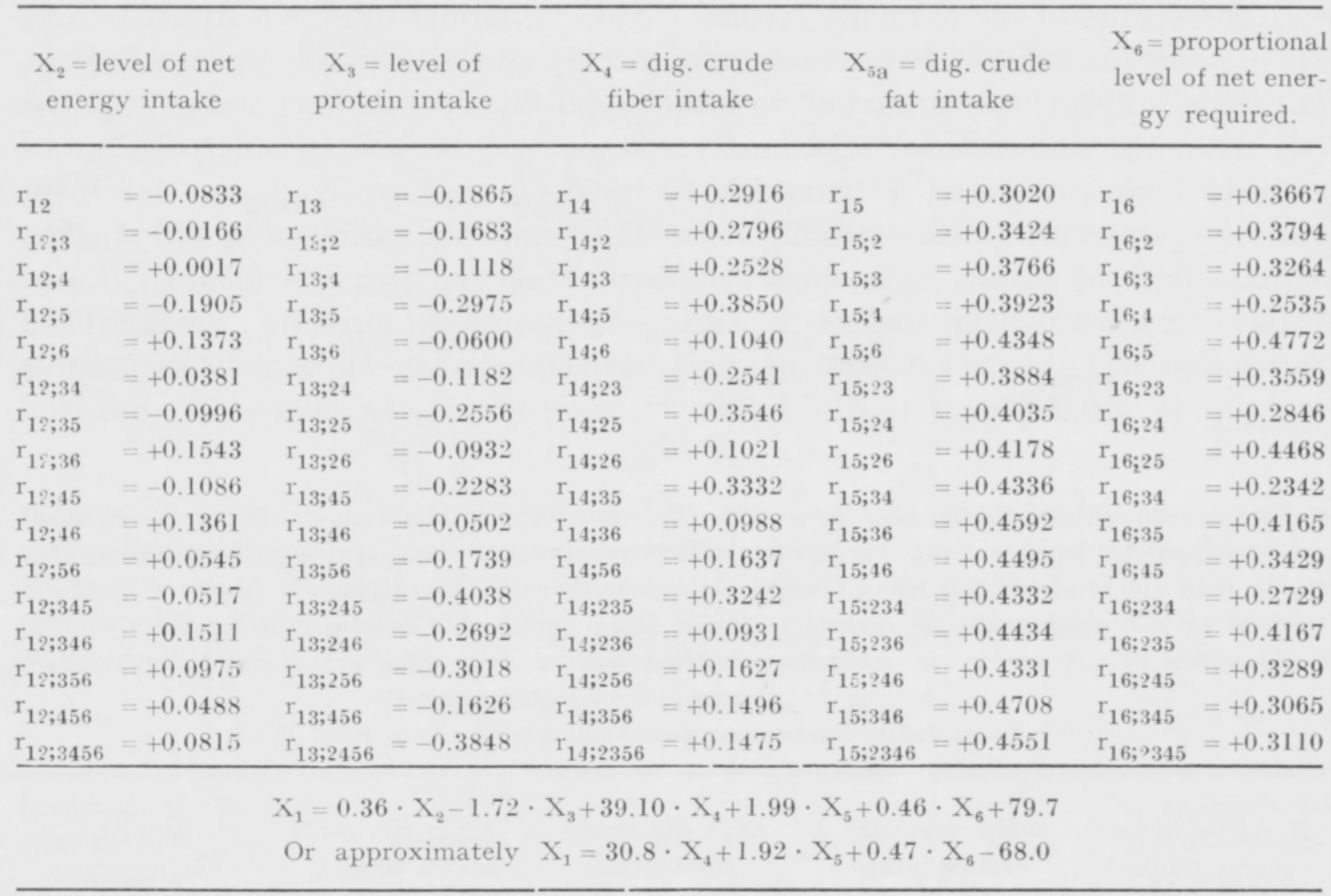

Regarding the digestible fat in the ration only the results obtained with variate $\mathrm{x}_{5 a}$ (dig crude fat grams per feed unit total required) are included in the table 3 . This variate has shown the highest coefficient of correlation. The difference is not very great if $\mathrm{x}_{5 b}$ (grams per $1000 \mathrm{~kg}$ live weight) is used instead of $\mathrm{x}_{5 a}\left(\mathrm{r}_{15 b ; 2346}=\right.$ $+0.6023)$. The regressions calculated using the variate $\mathrm{x}_{5 a}$, however, appeare to have tallied slightly better with te results obtained with the group and period test methods.

The digestible crude fiber in the ration $\left(\mathrm{x}_{4}\right)$ has shown a slight positive coefficient of correlation $\left(\mathrm{r}_{14 ; 2356}=+0.2675\right)$. It must further be noted that in these trials protein overfeeding $\left(\mathrm{x}_{3}\right)$ apparently has increased the plasma cholesterol content $\left(\mathrm{r}_{13 ; 2456}=+0.5210\right)$, but energy overfeeding $\left(\mathrm{x}_{2}\right)$ appears to have been practically ineffective $\left(\mathrm{r}_{12: 3456}=-0.0790\right)$ in this respect.

The results obtained from barren cows in normal condition (trials I-IX) are presented in table 4. As can be seen from this table most of the factors under study have not shown any distinct effect on the plasma cholesterol when experimenting with barren cows. The fat in feed $\left(\mathrm{x}_{\tilde{z} a}\right)$ alone appears to have been fairly effective $\left(\mathrm{r}_{15 ; 2346}\right.$ 
$=+0.2153)$. The average for plasma cholesterol in this group has been $175.6 \mathrm{mg} / 100 \mathrm{ml}$ which is higher than that for normally fertilized cows in the same trials $(M=164.8$, see table 2). These results appear to show that the mechanism normally regulating the level of plasma cholesterol has been disturbed in the case of these barren cows.

The results of the normally fertilized cows in higher condition (trials X-XII) are presented in table 5 . In the case of these well conditioned cows variates $\mathrm{x}_{4}-\mathrm{x}_{6}$ have shown parallel effects to those presented in table 3 . In this case the coefficients of correlation, however, are somewhat lower than in the case of the cows in normal condition. Further the mean level of plasma cholesterol in these well conditioned cows also $(226.4 \mathrm{mg} / 100 \mathrm{ml})$ has been appreciably higher than in cows in normal condition $(164.8 \mathrm{mg} / 100 \mathrm{ml})$. Neither in this case does the level of net energy intake $\left(\mathrm{x}_{2}\right)$ appear to show any distinct correlation with the plasma cholesterol content. Together all of these results appear to show, that the degree of fatness rather than a temporary energy overfeeding or underfeeding is the factor that affects the level of plasma cholesterol in dairy cows. It has to be noted also that the effect of the level of protein in the ration has been in the case of the well conditioned cows opposite to that observed in cows in normal condition.

Table 6. Coefficients of partial correlation when the cholesterol in blood plasma $\left(\mathrm{X}_{1}=\mathrm{mg} / 100 \mathrm{ml}\right)$ is considered as the dependent variable and the level of net energy intake $\left(\mathrm{X}_{2}=\%\right.$ of the requirements) the level of dig. crude prot. intake $\left(\mathrm{X}_{3}=\%\right.$ of the requirements), the dig. crude fiber intake $\left(\mathrm{X}_{4}=\right.$ $\mathrm{kg} / 1000 \mathrm{~kg}$ live weight), the dig. crude fat intake $\left(\mathrm{X}_{5 \mathrm{a}}=\mathrm{g} /\right.$ feed unit total required) and the total requirement of net energy in proportion to the requirements for maintenance and foetus $\left(\mathrm{X}_{\epsilon}=\right.$ fu.t.req. $/ \mathrm{fu} \cdot \mathrm{m}+\mathrm{f})$ as independent variables.

Trials $X-X I I$. Well conditioned barren cows $(n=28)$.

\begin{tabular}{ccccc}
$\mathrm{X}_{2}=$ level of net & $\mathrm{X}_{3}=$ level of & $\mathrm{X}_{4}=$ dig. crude & $\mathrm{X}_{5 \mathrm{a}}=$ dig. crude & $\begin{array}{c}\mathrm{X}_{6}=\text { proportional } \\
\text { protein intake }\end{array}$ \\
fi ber intake & fat intake & $\begin{array}{c}\text { level of net ener- } \\
\text { gy required }\end{array}$ \\
\hline
\end{tabular}

\begin{tabular}{|c|c|c|c|c|c|c|c|c|c|}
\hline $\mathrm{r}_{12}$ & $=+0.3331$ & ${ }^{r_{13}}$ & $=+0.1686$ & $\mathrm{r}_{14}$ & $=+0.3576$ & $\mathrm{r}_{15}$ & $=+0.7334$ & ${ }^{r_{16}}$ & $=-0.4583$ \\
\hline $\mathrm{r}_{12 ; 3}$ & $=+0.3292$ & $\mathrm{r}_{13 ; 2}$ & $=+0.1600$ & $\mathrm{r}_{14 ; 2}$ & $=+0.3393$ & $\mathrm{r}_{15 ; 2}$ & $=+0.7024$ & $\mathrm{r}_{16 ; 2}$ & $=-0.3359$ \\
\hline $\mathrm{r}_{12 ; 4}$ & $=+0.3130$ & $\mathrm{r}_{13 ; 4}$ & $=+0.0561$ & $\mathrm{r}_{14 ; 3}$ & $=+0.3243$ & $\mathrm{r}_{15 ; 3}$ & $=+0.7241$ & $\mathrm{r}_{16 ; 3}$ & $=-0.4517$ \\
\hline $\mathrm{r}_{12 ; 5}$ & $=+0.1591$ & $\mathrm{r}_{13 ; 5}$ & $=+0.0110$ & $\mathrm{r}_{14 ; 5}$ & $=+0.6557$ & $\mathrm{r}_{15 ; 4}$ & $=+0.8355$ & $r_{16 ; 4}$ & $=-0.5029$ \\
\hline $\mathrm{r}_{12 ; 6}$ & $=+0.0403$ & $r_{13 ; 6}$ & $=+0.1450$ & $\mathrm{r}_{14 ; 6}$ & $=+0.4186$ & $\mathrm{r}_{15 ; 6}$ & $=+0.6441$ & $\mathrm{r}_{16 ; 5}$ & $=+0.0023$ \\
\hline $\mathrm{r}_{12 ; 34}$ & $=+0.3127$ & $\mathrm{r}_{13 ; 24}$ & $=+0.0542$ & $\mathrm{r}_{14 ; 23}$ & $=+0.3074$ & $\mathrm{r}_{1523}$ & $=+0.6928$ & $\mathrm{r}_{16 ; 23}$ & $=-0.3298$ \\
\hline $\mathrm{r}_{12 ; 35}$ & $=+0.1594$ & $\mathrm{r}_{13 ; 25}$ & $=+0.0138$ & $\mathrm{r}_{14 ; 25}$ & $=+0.6464$ & $\mathrm{r}_{15 ; 24}$ & $=+0.8165$ & $\mathrm{r}_{16 ; 24}$ & $=-0.4163$ \\
\hline $\mathrm{r}_{12 ; 36}$ & $=+0.0416$ & $\mathrm{r}_{13 ; 26}$ & $=+0.1455$ & $\mathrm{r}_{14 ; 26}$ & $=+0.4189$ & $\mathrm{r}_{15 ; 26}$ & $=+0.6630$ & $\mathrm{r}_{16 ; 25}$ & $=+0$ \\
\hline $\mathrm{r}_{12 ; 45}$ & $=+0.0675$ & ${ }^{r} 13 ; 45$ & $=-0.3308$ & $\mathrm{r}_{14 ; 35}$ & $=+0.7014$ & $\mathrm{r}_{15 ; 34}$ & $=+0.8544$ & $\mathrm{r}_{16 ; 34}$ & $=-0$ \\
\hline $\mathrm{r}_{12 ; 46}$ & $=-0.0437$ & $\mathrm{r}_{13 ; 46}$ & $=+0.0043$ & $\mathrm{r}_{14 ; 36}$ & $=+0.4013$ & $\mathrm{r}_{15 ; 36}$ & $=+0.6343$ & $\mathrm{r}_{16 ; 35}$ & $=+1$ \\
\hline $\mathrm{r}_{12 ; 56}$ & $=+0.2085$ & $\mathrm{r}_{13 ; 56}$ & $=+0.0108$ & $\mathrm{r}_{14 ; 56}$ & $=+0.6568$ & $\mathrm{r}_{15 ; 46}$ & $=+0.7726$ & $r_{16 ; 45}$ & $=+0.0503$ \\
\hline $\mathrm{r}_{12 ; 345}$ & $=+0.0422$ & $\mathrm{r}_{13 ; 245}$ & $=-0.3266$ & $\mathrm{r}_{14 ; 235}$ & $=+0.6924$ & $\mathrm{r}_{15 ; 234}$ & $=+0.8373$ & $r_{16 ; 234}$ & $=-0.4132$ \\
\hline $\mathrm{r}_{12 ; 346}$ & $=-0.0438$ & $\mathrm{r}_{13 ; 246}$ & $=+0.0011$ & $\mathrm{r}_{14 ; 236}$ & $=+0.3971$ & $r_{15 ; 236}$ & $=+0.6537$ & $\mathrm{r}_{16 ; 235}$ & $=+0.1384$ \\
\hline $\mathrm{r}_{12 ; 356}$ & $=+0.2086$ & $r_{13 ; 256}$ & $=+0.0034$ & $r_{14 ; 256}$ & $=+0.6448$ & $\mathrm{r}_{15 ; 246}$ & $=+0.7763$ & $r_{16 ; 245}$ & $=+0.1214$ \\
\hline $\mathrm{r}_{12 ; 456}$ & $=+0.1296$ & $\mathrm{r}_{13 ; 456}$ & $=-0.3374$ & $\mathrm{r}_{14 ; 356}$ & $=+0.7040$ & $r_{15 ; 346}$ & $=+0.8014$ & $\mathrm{r}_{16 ; 345}$ & $=+0.0857$ \\
\hline $\mathrm{r}_{12 ; 3456}$ & $=+0.0160$ & $\mathrm{r}_{13 ; 2456}$ & $=-0.3356$ & $\mathrm{r}_{14 ; 2356}$ & $=+0.6935$ & $\mathrm{r}_{15 ; 2346}$ & $=+0.8045$ & $\mathrm{r}_{16 ; 2345}$ & $=+0.1460$ \\
\hline
\end{tabular}

$\mathrm{X}_{1}=0.03 \cdot \mathrm{X}_{2}-0.55 \cdot \mathrm{X}_{3}+81.6 \cdot \mathrm{X}_{4}+2.63 \cdot \mathrm{X}_{5}+0.21 \cdot \mathrm{X}_{6}-174.4$. 
Table 7. Equations showing the effect of the variates $\mathrm{X}_{2}-\mathrm{X}_{6}$ on the level of cholesterol in cow's blood plasma $\left(\mathrm{X}_{1}\right)$, expressed as a linear function of these variates.

1. Cows having been normally fertilized.

a. Cows in normal condition $\mathrm{X}_{1}=-0.21 \cdot \mathrm{X}_{2}+1.13 \cdot \mathrm{X}_{3}+7.95 \cdot \mathrm{X}_{4}+1.39 \cdot \mathrm{X}_{5}+9.51 \cdot \mathrm{X}_{6}-155.8$

b. Well conditioned cows $\quad \mathrm{X}_{1}=+0.36 \cdot \mathrm{X}_{2}-1.72 \cdot \mathrm{X}_{3}+39.1 \cdot \mathrm{X}_{4}+1.99 \cdot \mathrm{X}_{5}+0.46 \cdot \mathrm{X}_{6}+79.7$

\section{Barren cows}

a. Cows in normal condition $\mathrm{X}_{1}=+0.01 \cdot \mathrm{X}_{2}+0.20 \cdot \mathrm{X}_{3}+1.64 \cdot \mathrm{X}_{4}+0.30 \cdot \mathrm{X}_{5}+0.07 \cdot \mathrm{X}_{6}+118.0$

b. Well conditioned cows $\quad \mathrm{X}_{1}=+0.03 \cdot \mathrm{X}_{2}-0.55 \cdot \mathrm{X}_{3}+81.6 \cdot \mathrm{X}_{4}+2.63 \cdot \mathrm{X}_{5}+0.21 \cdot \mathrm{X}_{6}-174.4$

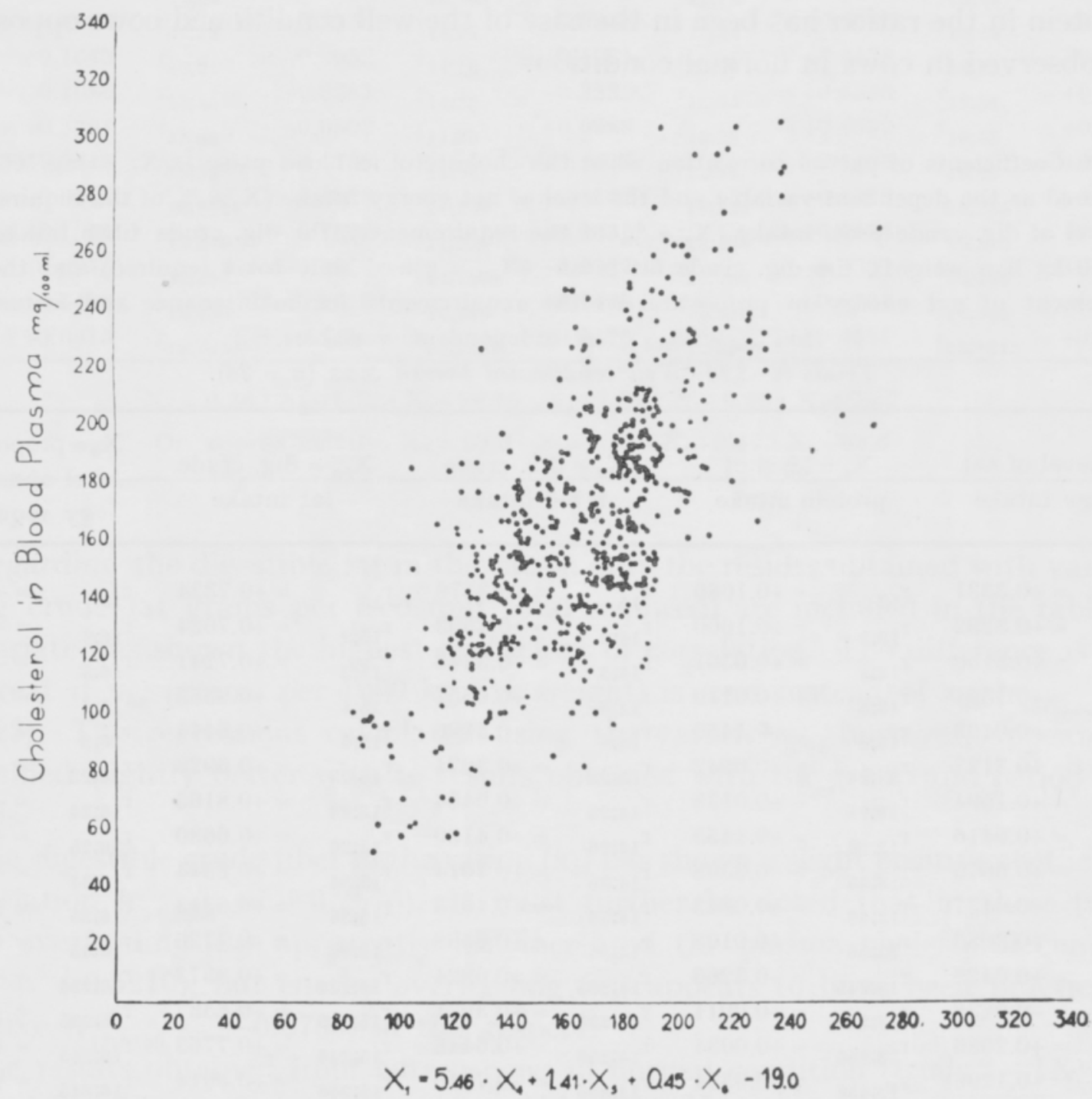

Fig. 2. The simultaneous effects of the dig. crude fiber $\left(\mathrm{x}_{4}\right)$, crude fat $\left(\mathrm{x}_{5}\right)$ and the proportional level of the net energy intake $\left(\mathrm{x}_{6}\right)$ on the cholesterol content of the blood plasma. Trials I-IX, normal cows in normal condition. 

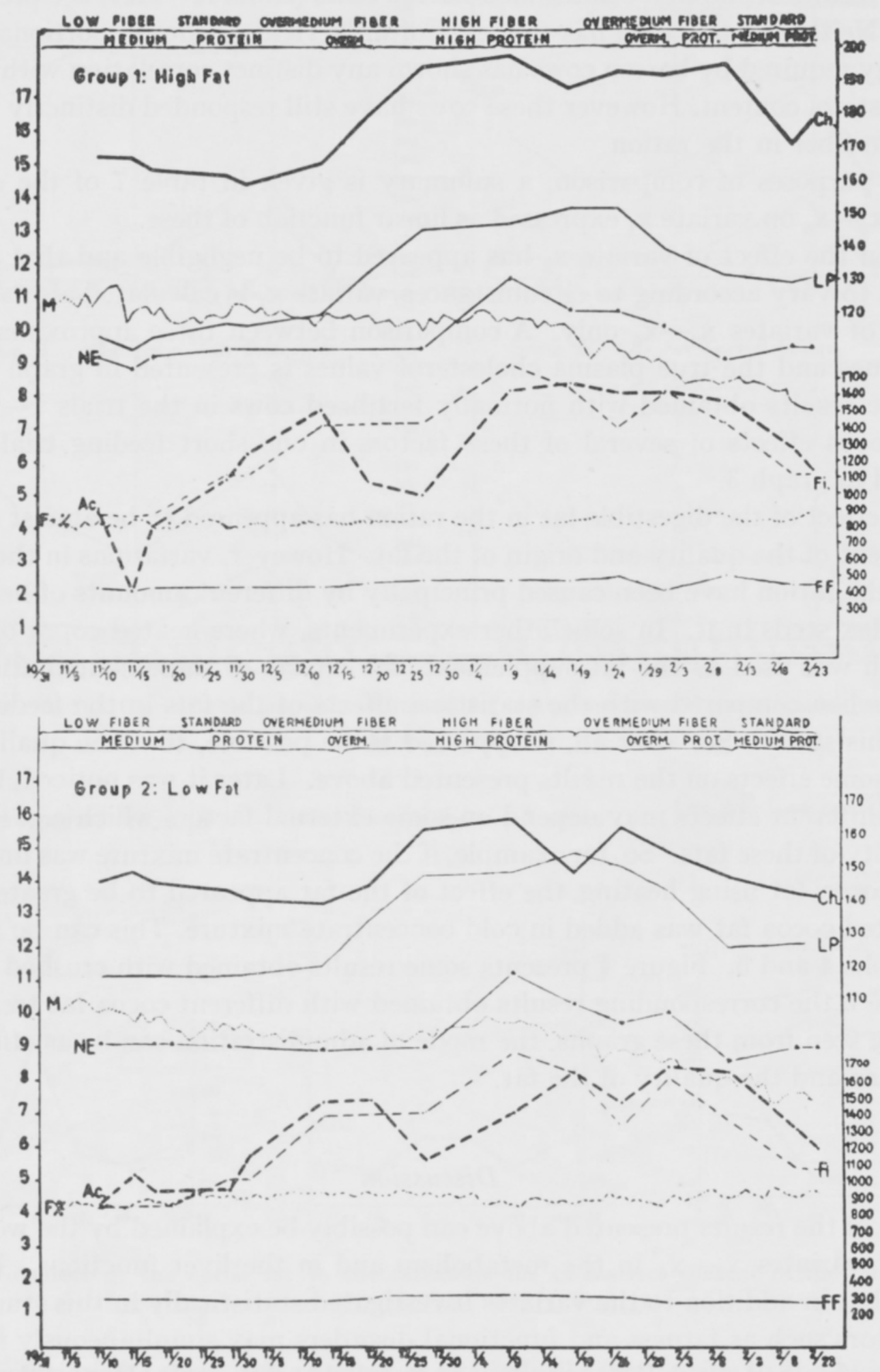

Fig. 3. The influence of the type of feeding on the cholesterol in the blood plasma and the volatile fatty acids in the blood, when the amount of fat in the ration is kept constant. The values represent the averages for single groups. $\mathrm{Ch}=$ cholesterol in the blood plasma $(\mathrm{mg} / 100 \mathrm{ml}), \mathrm{LP}=$ level of digestible crude protein (pct. of the requirements), $\mathrm{M}=$ milk yield $(\mathrm{kg} /$ day), $\mathrm{NE}=$ net energy in the ration (Sc. feed unit per day) $\mathrm{Ac}=$ volatile fatty acids in the blood $(\mathrm{mg} / 100 \mathrm{ml}), \mathrm{F}-\%=$ fat percentage in the milk, and $\mathrm{FF}=$ digestible crude fat in the ration (g/day). 
The results of the well conditioned barren cows (trials X-XII) are presented in table 6. Neither in this case has the level of milk yield or the proportional level of net energy required by barren cows has shown any distinct correlation with the plasma cholesterol content. However these cows have still responded distinctly to the fat and crude fiber in the ration.

For purposes of comparison, a summary is given in table 7 of the effects of variates $\mathrm{x}_{2}-\mathrm{x}_{6}$ on variate $\mathrm{x}_{1}$ expressed as linear function of these.

When the effect of variate $x_{2}$ has appeared to be negligible and that of $x_{3}$ has appeared to vary according to circumstances, variate $\mathrm{x}_{1}$ is calculated also as a linear function of variates $\mathrm{x}_{4}-\mathrm{x}_{6}$ only. A comparison between these approximate calculated values and the true plasma cholesterol values is presented in graph 2, which shows the results obtained with normally fertilized cows in the trials I-IX. The simultaneous effects of several of these factors in one short feeding trial are also presented in graph 3.

The effect of the digestible fat in the ration has appeared to be almost similarly independent of the quality and origin of the fat. However, variations in the amount of fat in the ration have been caused principally by different amounts of heated and crushed flax seeds in it. In some other experiments, where heated copra or cottonseed crush was used as the fat supplement, the effects of these contributions were minimal when compared with the statistical effects of the fats in the feeding stuffs used in this study. So, after all, it appeared to be possible, that the quality of fat had had some effects on the results presented above. Later it was noticed, however, that the different effects may depend on some external factors which e.g. lower the digestibility of these fats. So, for example, if the concentrate mixture was impregnated with cocoa fat using heating, the effect of the fat appeared to be greater than if pure melted cocoa fat was added in cold concentrate mixture. This can be seen a.a. from graphs 4 and 5. Figure 4 presents some results obtained with crushed linseeds, and figure 5 the corresponding results obtained with different cocoa fat treatments. As can be seen from these graphs, the mode of administration can be as effective as the amount and the quality of the fat.

\section{Discussion}

Most of the results presented above can possibly be explained by the wellknown effects of variates $\mathrm{x}_{2}-\mathrm{x}_{6}$ in the metabolism and in the liver functions. It is also possible that in addition to the variates investigated statistically in this study, some other factors such as fatness and functional disorders may simultaneously influence the results obtained. Such influence may be parallel or divergent. Hence, the statistical effects of the variates under investigation may vary appreciably. So, e.g. it is understandable that the effect of the level of energy requirement appears to be lower statistically, if the fatness or the disorders causing barreness have exerted additional stress on the metabolism. Similarly it is a known fact that the excess of protein in the ration has to be judged differently in animals on normal ration than in obesity and when a high fat diet is used. 

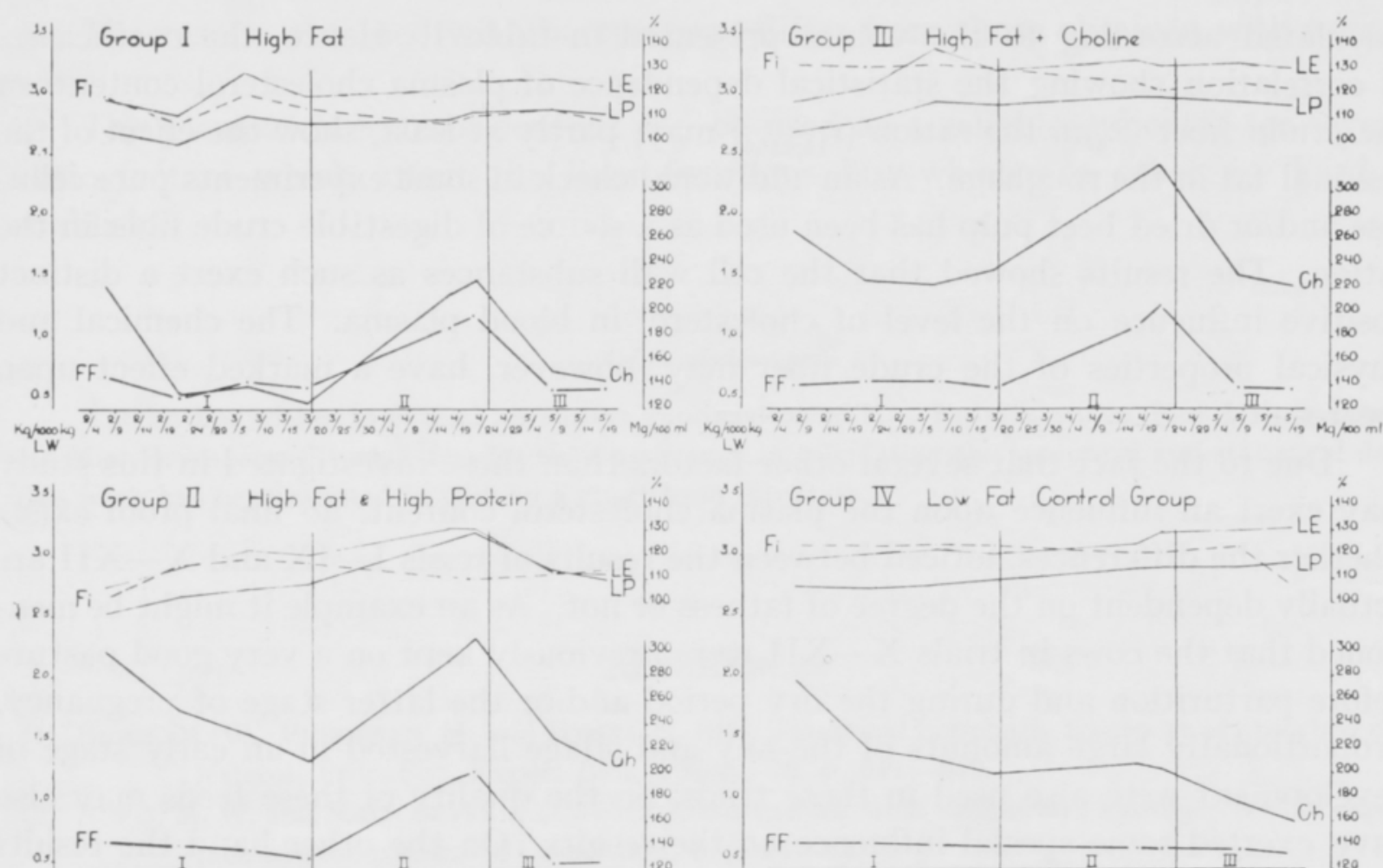

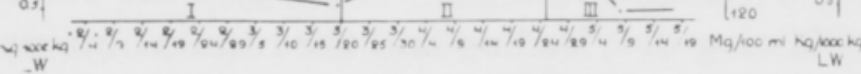

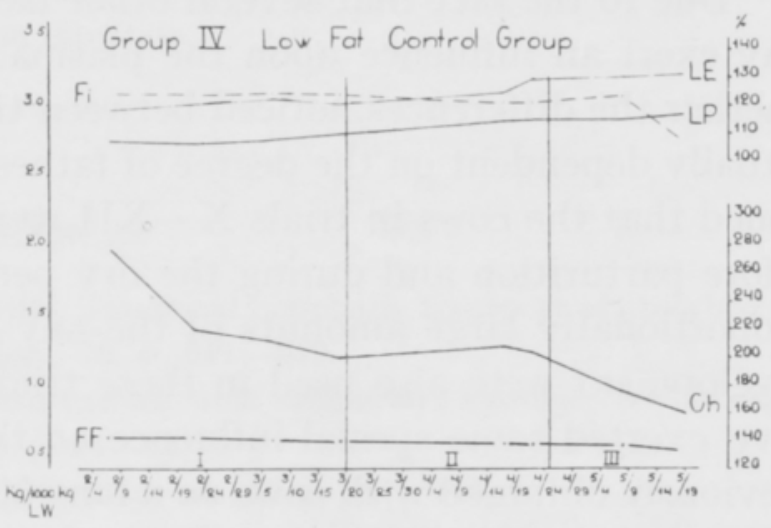

Fig. 4. The effect of the variable amounts of linseed fat in the ration on the cholesterol content of the blood plasma.

Group I impregned with cocoo tat
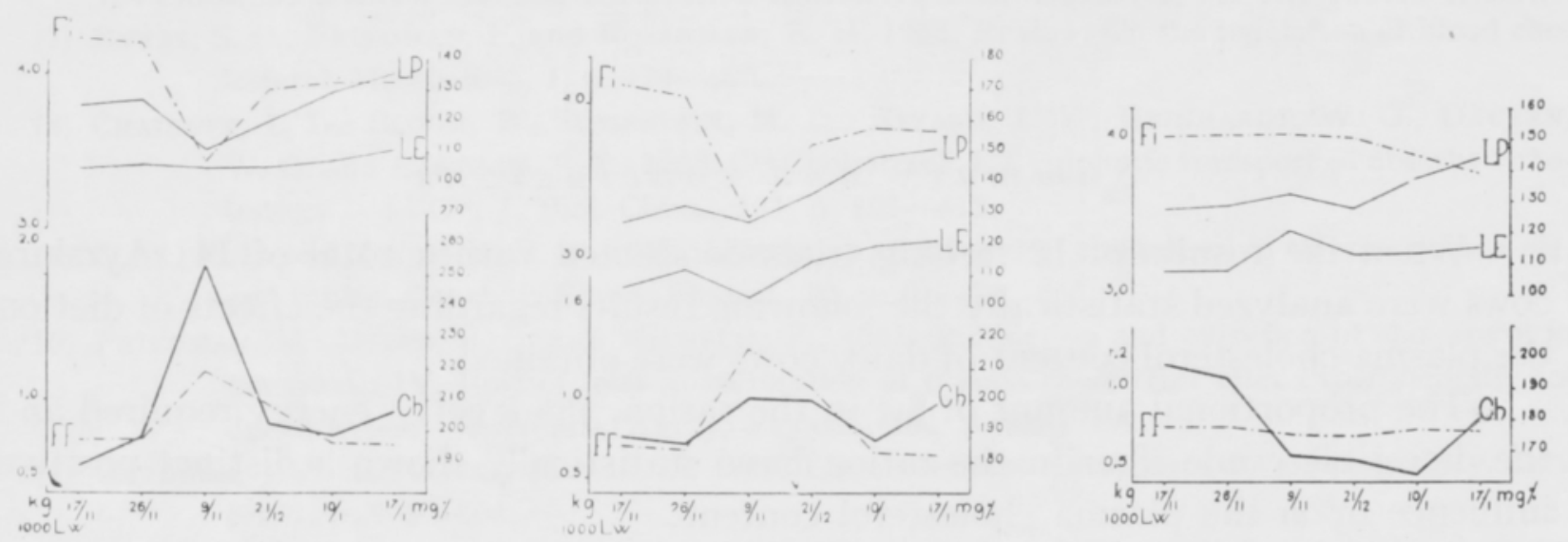

Fig. 5. The effect ot the cocoa fat in the ration on the cholesterol content of the blood plasma.

As mentioned before, the amount of the volatile fatty acids in the blood, which can serve as precursors for cholesterol, is distinctly affected by the amount of the digestible crude fiber in the ration (25). Hence, the positive effect of the crude fiber on the plasma cholesterol content, noticed in this study, appears to be what one would expect. It must be observed however, that the Soxhlet method used in this study for determing the crude fat, is highly unreliable (21). The actual amount or digestible crude fat especially in roughages apparently have been higher than the amounts 
calculated according to the values presented in table 1. Hence, the coefficients of correlation showing the statistical dependence of plasma cholesterol content on the crude fiber $\left(\mathrm{x}_{4}\right)$ in the ration $\left(\mathrm{r}_{14 ; 2356}\right)$ may, partly at least, show the effect of the residual fat in the roughage. As an additional check in some experiments pure cellulose and/or dried beet pulp has been used as a source of digestible crude fiber in the ration. The results showed that the cell wall substances as such exert a distinct positive influence on the level of cholesterol in blood plasma. The chemical and physical properties of the crude fiber may, however, have a marked effect upon the results.

Due to the fact that several other factors than those investigated in this study may exert an influence upon the plasma cholesterol content, no final proof exists whether the differences noticed between the results of trials I-IX and X-XII are actually dependent on the degree of fatness or not. As an example it might be mentioned that the cows in trials X-XII were previously kept on a very good pasture before parturition and during the dry period and/or the latter stage of pregnancy. Proportionally large amounts of the hay and silage harvested in an early stage of development were also used in these trials. So the quality of these feeds may also have exerted some special influence on the results. On the other hand the results previously obtained with cows on a long lasting overfeeding and the results obtained with humans (16), appeare to support the view, that the degree of fatness as such may influence the plasma cholesterol content of dairy cows.

The most important fact established in this study is that the plasma cholesterol content of dairy cows can serve as a very sensitive indicator for several dietic factors which affect the liver functions but which otherwise are very hard to observe.

\section{Summary and conclusions}

When the results of 12 feeding trials conducted with a total of 141 Ayrshire cows were analyzed statistically the following results regarding the effects of diet on the plasma cholesterol content of dairy cows were obtained.

The proportional amount of fat in the ration, the level of energy required and the digestible crude fiber in the ration have statistically shown a distinct positive influence upon the plasma cholesterol content.

The statistical dependence of plasma cholesterol content on the level of digestible crude protein in the ration has varied according to the circumstances showing a positive correlation in cows in normal condition and negative correlation in case of well conditioned cows.

A temporary energy overfeeding or slight underfeeding have not shown any distinct effect upon the plasma cholesterol content.

An increase in the degree of fatness appeares to increase the level of cholesterol in blood plasma appreciably.

The age of cows (2-13 years) apparently does not affect the level of plasma cholesterol. 
The results obtained with barren cows differ from those obtained with normal cows,

The plasma cholesterol content can be used as a reliable indicator for several dietic factors which affect the liver functions but which are otherwise hard to establish.

\section{Acknowledgements}

The author wishes to extend his sincere appreciation to Mrs. Katri Saarinen, Miss Kerttu Östring and Miss Eeva-Liisa Silvennoinen for their assistance in calculating the analytical and statistical data. This work has been assisted in part by a grant from the State.

\section{REFERENCES}

(1) Biggs, M. W., Friedman, M. and Byers, S. 1951. Intestinal lymphatic transport of absorbed cholesterol. Proc. Soc. Exper. Biol. \& Med., 78, p. 641-643.

(2) Biggs, M. W. and Kritchevsky, D. 1951. Observations with radioactive hydrogen $\left(\mathrm{H}^{3}\right)$ in experimental atherosclerosis. Circulation, 4, p. $34-42$.

(3) Boyd, E. M. 1934. The lipemia of pregnancy. J. Clin. Invest., 13, p. 347 -363.

(4) Brady, R. and Gurin, S. 1951. The synthesis of radioactive cholesterol and fatty acids in vitro. J. Biol. Chem., 189, p. $371-377$.

(5) Bürger, M. 1928. Cholesterinhaushalt beim Menschen. Ergebn. inn. Med. Kinderh., 34, p. 588 - 701.

(6) Byers, S. O., Friedman, M. and Michaelis, F. 1951. Observations concerning the production and excretion of cholesterol in mammals: III. The source of excess plasma cholesterol after ligation of the bile duct. J. Biol. Chem., 188. p. $637-641$.

(7) Byers, S. O., Friedman, F. and Rosenman, R. H. 1952. Review: On the regulation of blood cholesterol. Metabolism, 1, p. 479-503.

(8) Chaikoff, I. L., Bloom, B., Siperstein, M. D., Kiyasu, J. Y., Reinhardt, W. O., Dauben, W. G. and Eastham, J. F., 1952. C $^{14}-$ Cholesterol: I. Lymphatic transport of absorbed cholesterol $-4-\mathrm{C}^{14}$. J. Biol. Chem., 194, p. 407-412.

(9) Соок, R. P. and Thomson, R. O. 1951. Absorption of fat and of cholesterol in the rat, guinea pig, and rabbit. Quart. J. Exper. Physiol., 36, p. 61-74.

(10) Friedman, M., Byers, S. O. and Michelis, F., 1951. Production and excretion of cholesterol in mammals: IV. Role of liver in restoration of plasma cholesterol after experimentally induced hypocholesteremia. Am. J. Physiol., 164, p. 789-791.

(11) Gardner, J. A. and Gainsborough, H. 1929. The cholesterol metabolism during pregnancy. Lancet, 1, p. $603-606$.

(12) Gould, R. G., Campbell, D. J., Taylor, C. B., Kelly, F. B. JR., Warner, I. and Davis, C. B. JR. 1951. Origin of plasma cholesterol using carbon ${ }^{14}$. Fed. Proc. 10, p. 191.

(13) Horlick, L., Feldman, M. Jr., and Katz, L. N. 1948. Disappearance of cholesterol following its intravenous injection in physiologically emulsified form. Proc. Soc. Exper. Biol. \& Med., 68 , p. $243-245$.

(14) Jones, H. B., Gofman, J. W., Lindgren, F. T., Lyon, T. P., Graham, D. M., Strisower, B., and Nichols, A. W. 1951. Lipoproteins in atherosclerosis. Am. J. Med., 11. p. 358 - 380.

(15) KeYs, A. 1952. The cholesterol problem. Voeding, 13, p. 539-555.

(16) KEYs, A. 1953. Atherosclerosis: A problem in newer public health. J. of the Mount Sinai Hospital, 20 , p. $118-139$.

(17) Little, H. N. and Bloch, K. 1950. Studies on the utilization of acetic acid for the biological synthesis of cholesterol. J. Biol. Chem., 183, p. 33-46. 
(18) Moses, C., Rhoder, G. L., Leatham, E. and George, R. S. 1952. Effect of cholesterol feeding during pregnancy on blood cholesterol levels and placental vascular lesions. Circulation, 6, p. 103-105.

(19) Prhl, A., Bloch, K. and Anker, H. S. 1950. The rates of synthesis of fatty acids and cholesterol in the adult rat studied with the aid of labeled acetic acid. J. Biol. Chem., 183, p. 441-450.

(20) PoIJÄrvi, I. 1925. Suomalaisen lypsykarjan ravinnon tarve käytännöllisten ruokintakokeiden valossa. Maatalouskoelaitoksen tieteellisiä Julkaisuja, 26, p. 1-137.

(21) RıNG, O. 1947. Tutkimuksia rehunrasvan määrittämisestä saippuoimalla sekä rasvan sulavuudesta märehtijöillä (Summary: Studies on determination of feed fat with saponification and on digestibility of fat in ruminants). Acta Agralia Fennica, 64, 2, p. 1-127.

(22) SaArinen, P. 1938. Einfaches Verfahren zur Gewinnung von Arterienblutproben beim Rindvieh. Maataloustiet. Aikakauskirja (J. Sci. Agr. Soc. Finland), 10, p. 140-146.

(23) SaARINen, P. 1944. Lehmän veriplasman lipoidiaineosien vaikutuksesta maitorasvan muodostukseen. (Ref. Über den Einfluss einiger Lipoidbestandteile im Blutplasma der Kuh auf die Milchfetterzeugung). Acta Agralia Fennica, 57, 2, p. 1-131.

(24) SaArinen, P. and Shaw, J. C. 1950. Studies on ketosis in dairy cattle XI. Lipids, minerals and ascorbic acid in the blood of cows with spontaneous ketosis. J. Dairy Sci., 33, p. 496-507.

(25) SaARINEN, P. 1955. On the nutritional factors affecting the level of volatile fatty acids in cows' peripheral blood. Acta Agralia Fennica, 83, p. 133-146.

(26) Sprague, F. G. 1951. Cortisone and ACTH:A review of certain physiological effects and their clinical interpretations. Am. J. Med. 10, p. 567.

(27) Stepp, W. 1918. Über den Cholesteringehalt des Blutserums bei Krankheiten. Münch. med. Wochenschr., 65. p. $781-785$.

(28) Turner, R. H., Snavely, J. R., Goldwater, W. H., Randolph, M. L., Sprague, C. C., and Unglaub, W. G. 1951. The study of serum proteins and lipids with the aid of the quantity ultracentrifuge: I. Procedure and principal features of the centrifugate of untreated normal serum as determined by quantitative analysis of samples from 10 levels. J. Clin. Invest., 30 , p. $1071-1081$.

(29) $Z_{\mathrm{ABIN}}$, I. and $\mathrm{BLOch}, \mathrm{K}$. 1950. The utilization of isovaleric acid for the synthesis of cholesterol. J. Biol. Chem., 185, p. 131-138.

\section{SELOSTUS:}

\section{RAVINTO JA LYPSYLEHMIEN VERIPLASMAN KOLESTEROLIPITOISUUS}

\section{Helsingin yliopiston kotieläintieteellinen laitos.}

\section{Pellervo SaARINen}

Otsakkeessa mainittua kysymystä on tässä tutkimuksessa tarkastettu kahdentoista yhteensä 141 Ay-lehmällä suoritetun ruokintakokeen antamien tulosten valossa. Koetulokset on käsitelty tilastollisesti ja näin menetellen on päädytty seuraaviin johtopäätöksiin.

Sulavan raakarasvan ja raakakuidun määrät rehuannoksessa sekä eläinten energiantarpeen suhteellinen määrä ovat tilastollisesti positiivisessa vuorosuhteessa plasman kolesterolipitoisuuteen.

Sulavan raakavalkuaisen vaikutus on vaihdellut olosuhteista riippuen. Normaalikuntoisten lehmien kysymyksessä ollessa valkuaisen suhteellisen määrän ja plasman kolesterolipitoisuuden välinen vuorosuhde on ollut positiivinen, mutta lihavampien lehmien kysymyksessä ollessa se on ollut negatiivinen.

Hetkellisellä energiayliruokinnalla tai -aliruokinnalla ei ole ollut sanottavaa vaikutusta plasman kolesterolipitoisuuteen. 
Lehmän lihavuusasteen nousuun näyttää liittyvän veriplasman kolesterolipitoisuuden huomattavaa nousua.

Lehmän ikä ei normaalisen käyttöiän (2-13 v.) puitteissa näytä ainakaan sanottavasti vaikuttavan plasman kolesterolipitoisuuteen. neet eläimet.

Ruokintakokeissa mahoiksi jääneet lehmät ovat yleisesti reagoineet eri tavalla kuin terveinä pysy-

Lehmän veriplasman kolesterolipitoisuutta voidaan käyttää indikaattorina tutkittaessa eräitä sellaisia dieettisiä tekijöitä, jotka vaikuttavat maksan toimintoihin, mutta joiden vaikutus on muulla tavoin vaikeasti todettavissa. 